\title{
The copepodid stages of Drepanopus forcipatus Giesbrecht, with notes on the genus and a comparison with other members of the family Clausocalanidae (Copepoda Calanoida)
}

\author{
K. Hulsemann* \\ Biologische Anstalt Helgoland; Notkestraße 31, D-W-2000 Hamburg 52, \\ Federal Republic of Germany
}

\begin{abstract}
The post-naupliar developmental stages of the Calanoid copepod Drepanopus forcipatus Giesbrecht are described. They are compared with copepodids of other members of the family Clausocalanidae. The sequence of appearance and development of segmentation and setation indicate considerable conformity and point to a uniform familial pattern. Attention is drawn to a general pattern of addition of body segments and of segments in the first antenna and swimming legs. Comparison of integumental pore patterns of several genera confirms the provisional pore signature of the family. Remarks are made on the identity and distribution of species of Drepanopus.
\end{abstract}

\section{INTRODUCTION}

Drepanopus forcipatus Giesbrecht, family Clausocalanidae, lives, as its congeners in the southern hemisphere, $D$. pectinatus Brady and $D$. bispinosus Bayly, in inshore and shelf waters surrounding subantarctic/antarctic coasts. Though locally occurring in huge numbers, $D$. forcipatus is otherwise little known. The opportunity to get to know the juveniles of the species was provided by a plankton sample from the Discovery Collection from South Georgia (Hulsemann, 1985) that contained all copepodid stages in abundance. The morphology of ontogenetic developmental stages in crustaceans provide hints as to phylogenetic relationships among taxa. Calanoid copepods typically pass through six naupliar stages and five copepodid stages before they finally molt into adults. Formation of the various stages follows rules that govern ontogenetic development. Body segmentation of copepodids in conjunction with the progression of the development of the swimming legs readily permits determination of the stages. The investigation by Heron \& Bowman (1971) of the post-naupliar developmental stages of .Clausocalanus laticeps, C. brevipes and Ctenocalanus citer allow detailed comparison with these members of the family. Purpose of the present paper is presentation of the morphological development of the Drepanopus forcipatus copepodids. Further, comparison of the developmental stages and of other morphological features with those of representatives of other genera in the family Clausocalanidae contributes towards a better understanding of relationships within the family.

* Member of the Taxonomy Group at the Biologische Anstalt Helgoland 


\section{MATERIAL AND METHODS}

All specimens of Drepanopus forcipatus used in this study were removed from one large subsample apparently containing only this species. The sample had been collected north of the island of South Georgia at RV William Scoresby Station WS42 (Discovery Collections) at $54^{\circ} 42^{\prime} \mathrm{S}, 36^{\circ} 47^{\prime} \mathrm{W}$ on 7 January 1927 , depth of tow $0-5 \mathrm{~m}$. Species, specimens of which were utilized in a comparison of integumental pore patterns, and their collecting data are: Drepanopus forcipatus, Argentine Shelf, FRV Walther Herwig 36 Station $300,49^{\circ} 00^{\prime} \mathrm{S}, 65^{\circ} 00^{\prime} \mathrm{W}, 16$ February $1971,0-50 \mathrm{~m} ; \mathrm{D}$. pectinatus, Heard

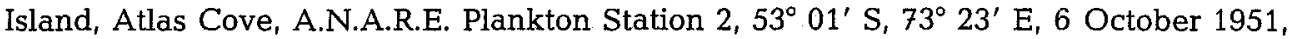
surface; Ctenocalanus vanus, Argentine Shelf, FRV Walther Herwig 36 Station $321,43^{\circ}$ $18^{\prime} \mathrm{S}, 62^{\circ} 30^{\prime} \mathrm{W}, 21$ February $1971,0-50 \mathrm{~m}$.

Intact specimens of Drepanopus forcipatus of nine categories, viz copepodid stages I, II, III, IV $q$, IV $\delta, V q, V \delta$, and adult $q$ and $\delta$, were transferred to drops of glycerine on microscopic slides until at least ten representatives of each had accumulated. The sample also contained some naupliar stages which, however, are not considered here. Measurements of prosome and urosome lengths were taken from the right side of the specimens under a dissecting scope at $50 \times$ magnification. As prosome length the distance was measured between the anterior end of the cephalon and - middorsally - the articulation separating prosome from urosome, and as urosome length the distance between the articulation and the distal end of the right furcal ramus disregarding any telescoping. Drawings of the copepodids in lateral view show only appendages of the right side. Appendages were usually dissected from the right side of the unstained animals and drawn without cover slips with the aid of a camera lucida. Feathering on the setae is omitted. Treatment of the copepods for study of their integumental pore patterns followed that described by Fleminger (1973) and Mauchline (1988): It involves digestion of the soft tissue in an aqueous solution of potassium hydroxide and staining of the integument in a solution of Chlorazole Black E in $70 \%$ ethanol.

\section{RESULTS}

Description of the copepodid stages

\section{Body}

Prosome (Figs 1-4, 6-10,12,14,16, 18, 20-22). In Drepanopus forcipatus, the cephalosome and first metasomal segment are completely separated in copepodid I while they are separated by a fine line in copepodid II. In subsequent stages this line is recognizable only dorsally. In adults, the cephalosome and first metasomal segment are completely fused. There are three metasomal segments in copepodid I and four segments in copepodids II to V whereby these represent segments I to IV in copepodid II, but segments II to V in copepodids III to V. - Rostral filaments appear for the first time in copepodid II.

Ur o s o m e (Figs 1-22). The urosome consists - besides of the caudal rami - of two segments in copepodids I to III, of three segments in copepodid IV, of four segments in copepodid $\mathrm{V}$ and the adult female, and of five free segments in the adult male. Either caudal ramus of copepodid I carries three terminal setae. The small and soft medial or 

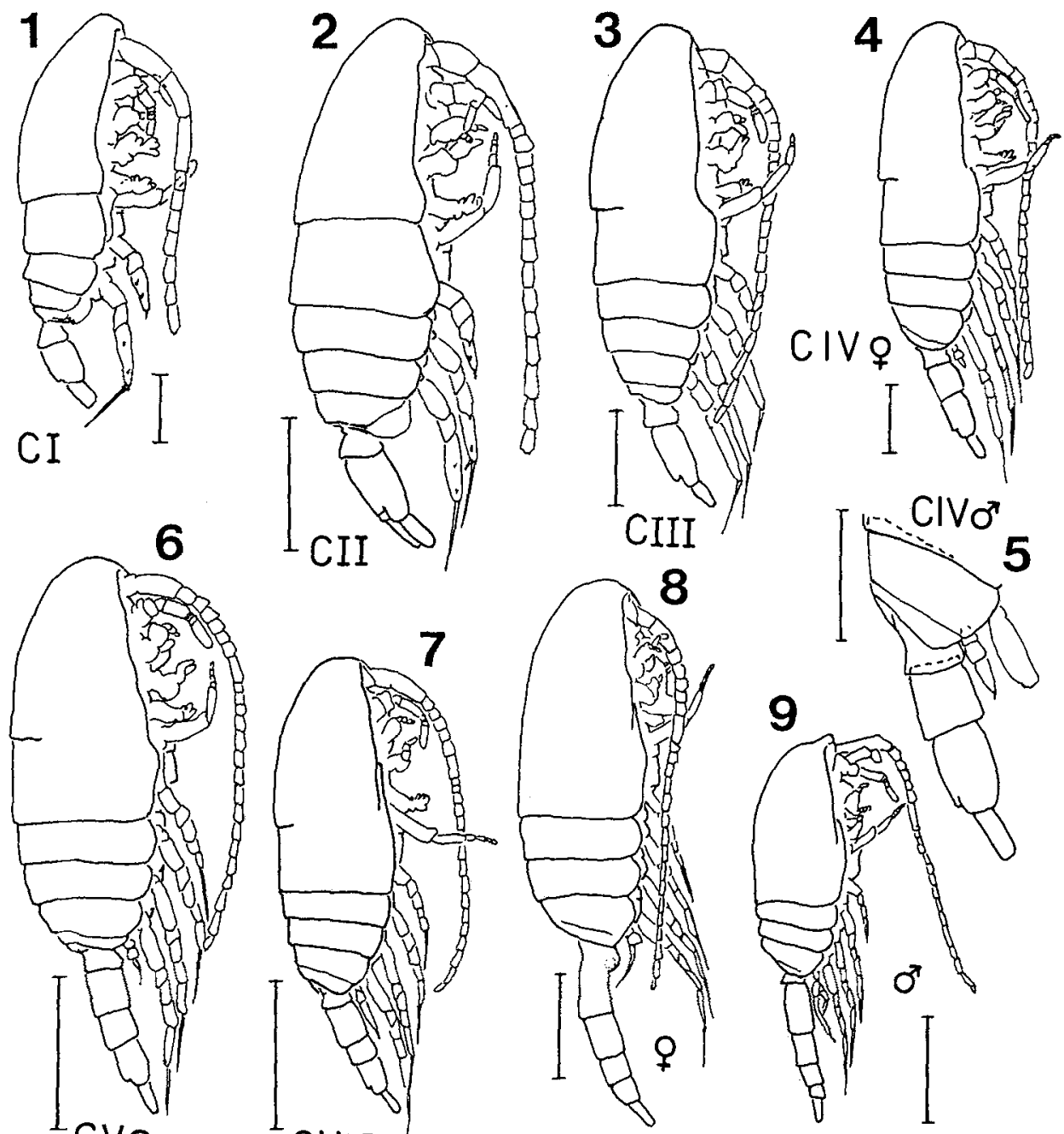

Figs 1-9. Drepanopus forcipatus. Copepodid stages I to V, adults, right lateral view. CI: copepodid stage I, CII: copepodid stage II etc. Scales. $0.2 \mathrm{~mm}$ : Figs 1-5; $0.5 \mathrm{~mm}$ : Figs 6-9

appendicular seta originates at about half-way the length, and just ventrad, of the medial margin. A minute spinule on the distal lateral corner of the ramus may indicate the lateral seta. In copepodid II, the bases of the inner and the middle terminal setae allow room for the bud of a further seta: its appearance in copepodid III completes the number of caudal setae. Their lengths could not be determined as the terminal setae were either broken short or lost in all juveniles on hand. In adults (Figs 23,24 ) the second terminal seta is the longest. It overreaches the other three by about one third its length in males; this difference is smaller in females. The terminal setae are rather straight in males, in females they are curved ventrad. 


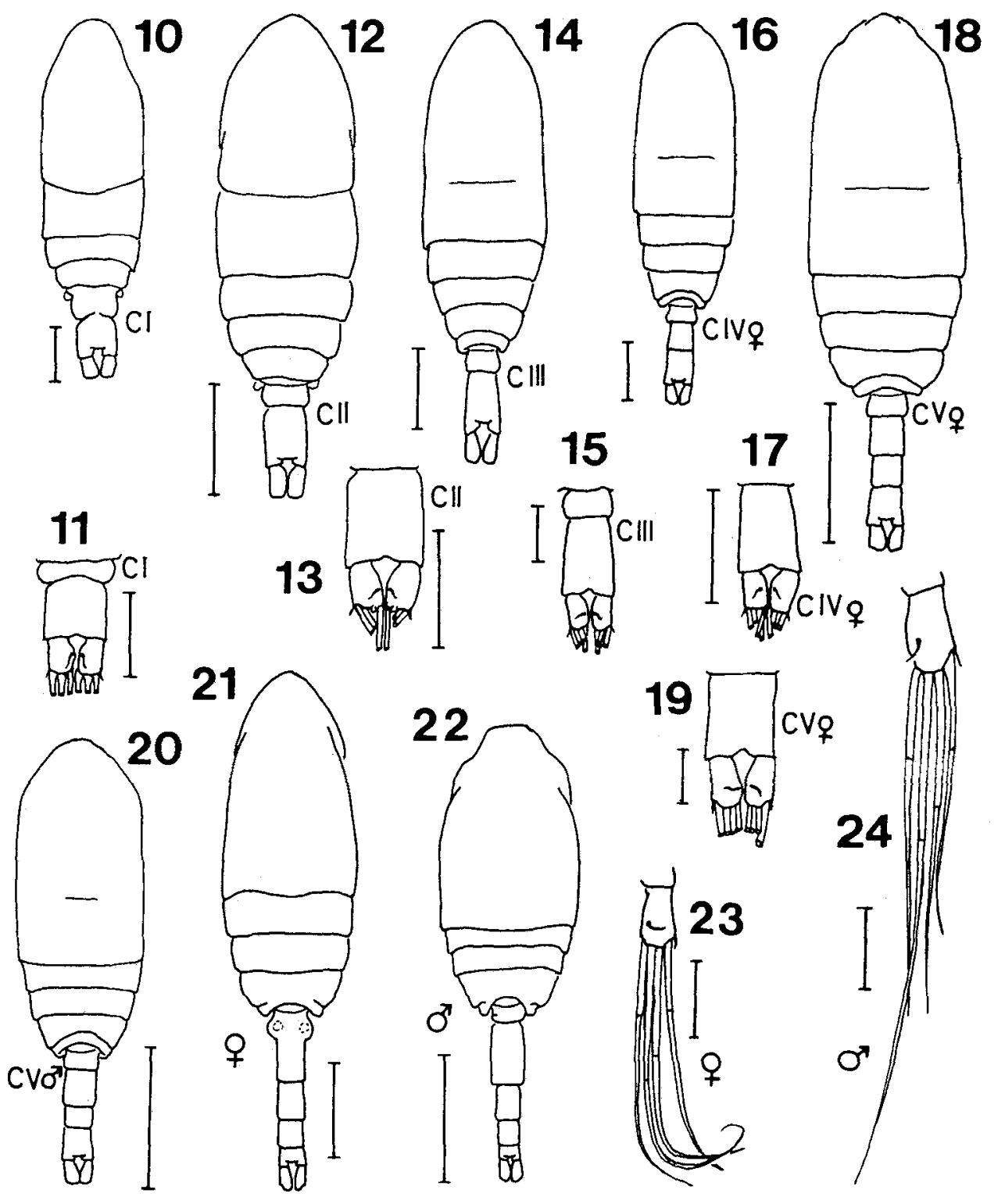

Figs 10-24. Drepanopus forcipatus. Copepodid stages I to V, adults. Figs 10, 12, 14, 16, 18, 20-22 dorsal view; Figs 11, 13, 15, 17, 19 anal segment, ventral view; Figs 23, 24 left caudal ramus, ventral view. Scales. $0.1 \mathrm{~mm}$ : Figs 11, 13, 15, 19, 23, 24; $0.2 \mathrm{~mm}$ : Figs 10, 12, 14, 16, 17; $0.5 \mathrm{~mm}$ : Figs 18, 20-22

In the three youngest copepodid stages the prosome: urosome length ratio remains constant. From copepodid IV on, this ratio decreases as the urosome lengthens. From copepodid $\mathrm{V}$ on, sexual dimorphism is expressed in the total length as well as in the prosome: urosome length ratio. Table 1 presents ranges and means of total lengths of 
Table 1. Drepanopus forcipatus. Mean $(\bar{x})$ and range of total length (TL), prosome length (P), urosome length $(U)$, and $P: U$ length ratio of randomly selected copepodid stages $I-V$ and adults. Measurements in $\mathrm{mm}$. For all copepodid categories sample size $\mathrm{n}=10$. Data for adults in part from Hulsemann (1985), sample size $n=30$

\begin{tabular}{|c|c|c|c|c|c|c|c|c|}
\hline \multirow[t]{2}{*}{ Stage } & \multicolumn{2}{|r|}{$\mathrm{TL}$} & \multicolumn{2}{|r|}{$\mathrm{P}$} & \multicolumn{2}{|r|}{$\mathrm{U}$} & \multicolumn{2}{|r|}{$\mathrm{P}: \mathrm{U}$} \\
\hline & $\overline{\mathbf{x}}$ & Range & $\overline{\mathbf{x}}$ & Range & $\bar{x}$ & Range & $\overline{\mathbf{x}}$ & Range \\
\hline I & 0.63 & $0.59-0.68$ & 0.48 & $0.44-0.52$ & 0.15 & $0.14-0.16$ & 3.21 & $2.88-3.43$ \\
\hline II & 0.83 & $0.74-0.90$ & 0.63 & $0.56-0.68$ & 0.20 & $0.18-0.22$ & 3.15 & $3.00-3.30$ \\
\hline III & 1.06 & $1.01-1.10$ & 0.81 & $0.76-0.84$ & 0.25 & $0.24-0.26$ & 3.19 & $3.03-3.33$ \\
\hline IV 9 & 1.39 & $1.34-1.52$ & 1.01 & $0.96-1.10$ & 0.38 & $0.36-0.42$ & 2.69 & $2.52-2.83$ \\
\hline IV 0 & 1.39 & $1.36-1.44$ & 1.01 & $0.98-1.04$ & 0.38 & $0.36-0.40$ & 2.68 & $2.50-1.89$ \\
\hline $\mathrm{V}$ 웅 & 1.84 & $1.72-2.00$ & 1.27 & $1.20-1.36$ & 0.56 & $0.52-0.64$ & 2.26 & $2.13-2.39$ \\
\hline Vo & 1.64 & $1.50-1.78$ & 1.15 & $1.06-1.24$ & 0.50 & $0.44-0.56$ & 2.32 & $2.11-2.44$ \\
\hline 우 & 2.43 & $1.84-2.74$ & 1.59 & $1.24-1.82$ & 0.83 & $0.60-0.96$ & 1.92 & $1.79-2.07$ \\
\hline$\delta$ & 1.84 & $1.66-1.94$ & 1.14 & $1.02-1.22$ & 0.70 & $0.64-0.74$ & 1.63 & $1.56-1.73$ \\
\hline
\end{tabular}

prosome and urosome, and prosome: urosome length ratios of copepodid stages I to $\mathrm{V}$ and of adults. The younger stages are well separated by size; considerable overlap in size is found between stages $\mathrm{V}$ and adults.

\section{Appendages}

C e p h a l o s o m e. The first antenna (Figs 25-32) of copepodid I consists of ten free segments. The proximal three segments are here interpreted as precursors of segments $1-3,4-9$, and 10-18, respectively, of the basic adult complement of 25 free segments. One long seta on each composite segment would then be forerunner of that on future segments 3,7 , and 18 , respectively. The seven distal segments correspond to segments 19-25 of the adult. Segments 19 and 25 bear one aesthetasc each on the anterior distal margin. - The first antenna of copepodid II is composed of 17 free segments. Segments 1 , 7,14 , and 18 of the adult are separated, and 8 and 9 only so by a fine line. Besides three setae on the first segment, there is one seta each on the still united segments 2 and 3 , and on $7,9,14$, and 18; in addition, segments 2,3 , and 9 each carry one aesthetasc. Both segments 20 and 22 gained one anterior seta. Segments $4 \sim 6,10 \sim 13$, and $15 \sim 17$ are short and unarmed. - In copepodid III there are 22 free segments, segments $2 \sim 3,4 \sim 5$ as well as $8 \sim 9$ being fused. Segment 5, still united with segment 4 , and segments 11 to 13 and 15 to 17 , separated for the first time, bear one seta each. Further, segments 5 and 14 carry one aesthetasc. - With the fourth copepodid stage the first antenna attains the number of segments of the adult female, i.e., 24 free segments, all but 8 and 9 being separated. One distal seta is found for the first time on segments $2,4,6,8$, and 10 , and one additional middle seta on segments $2,4,14$, and 18 . There is one further aesthetasc on segment 12 thus bringing up the total to eight, a number that is maintained through copepodid $V$ and the adult female. The number of segments in the first antenna and their armature agree in both female and male copepodids IV. - In copepodid V one further seta is added to each of the three sites of the second segment and one middle seta each on segments 3,5 , $6,7,8,9$, and 12 . Complete agreement in the armature of the first antenna exists also between female and male copepodid V. - This armature fully corresponds to that of the 


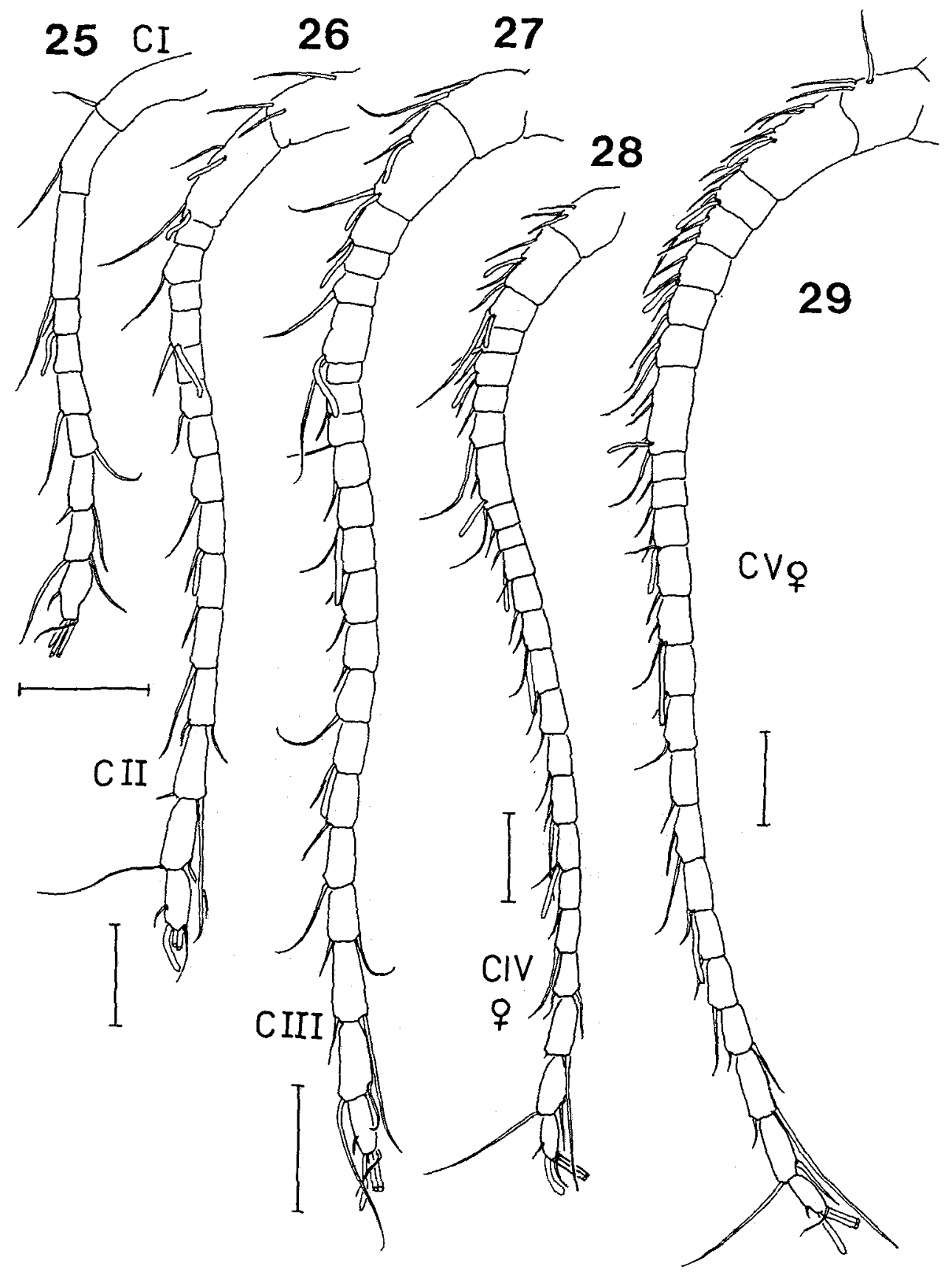

Figs 25-29. Drepanopus forcipatus. Right first antenna, ventral view, copepodid stages I to V. Scales. $0.1 \mathrm{~mm}$ 


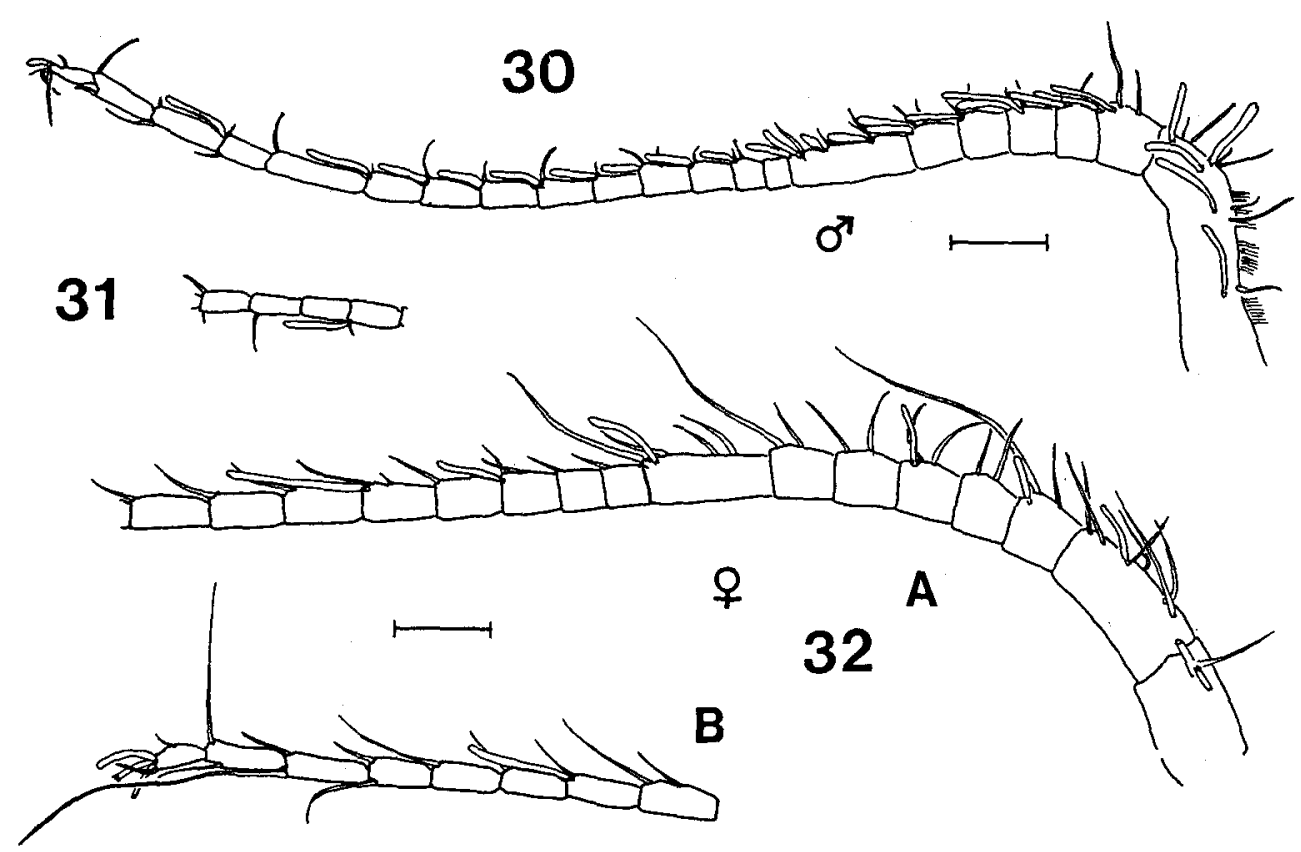

Figs 30-32. Drepanopus forcipatus. First antenna, ventral view, adults. Figs 30, 32 right side; Fig. 31 left side, segments 19-22; Fig. 32A segments 1-17; Fig. 32B segments 18-25. Scales. $0.1 \mathrm{~mm}$

adult female except that in the latter the distal setae on segments $3,7,9$, and 18 are still more elongated. - The first antenna of the adult male shows strong sexual dimorphism by (1) fusion of segments 1 and 2, on the right side also of segments 20 and 21 , and incomplete fusion of segment 10 with $8 \sim 9$; (2) presence of three prominent patches of fleshy spinules on the fused segment $1 \sim 2 ;(3)$ increase in the number of aesthetascs and decrease of overall size and reduction in number of setae. In all, there are 20 aesthetascs more than in copepodid $\mathrm{V}$ or the adult female. The middle aesthetasc on segment 9 is club-shaped. Suppressed are the distal setae on segments 10 and 11 and the middle seta on segment 18. The distal seta on segment 12 is modified to a short, pointed process.

In the second antenna (Figs 33-39), segmentation of the exopod in copepodids I and II is incomplete, although the number of setae corresponds to that of the adult. Basal segments and endopod of copepodid I are developed as in the adult except for the number of setae on the second endopodal segment. Here, one or two setae are added at each consecutive stage to the 4 and 6 setae on the inner and outer lobe, respectively, until a complement of $9 / 7$ setae is attained in adults.

Also the mandible palpus (Figs $40,42,44,46,48,49,51,53$ ) in copepodid I is developed as in the adult, except, again, for the number of setae on the second endopodal segment. To the six setae in copepodid I one seta is added at each subsequent stage to reach 11 in the adult female; in the adult male this number is reduced again to nine. - The edge of the mandible blade (Figs $41,43,45,47,50,52,54$ ) carries in copepodid I, somewhat recessed from the ventral margin, three widely-spaced central teeth, four narrowly-spaced dorsal teeth, and one setulose seta at the dorsal end. In copepodid II one 

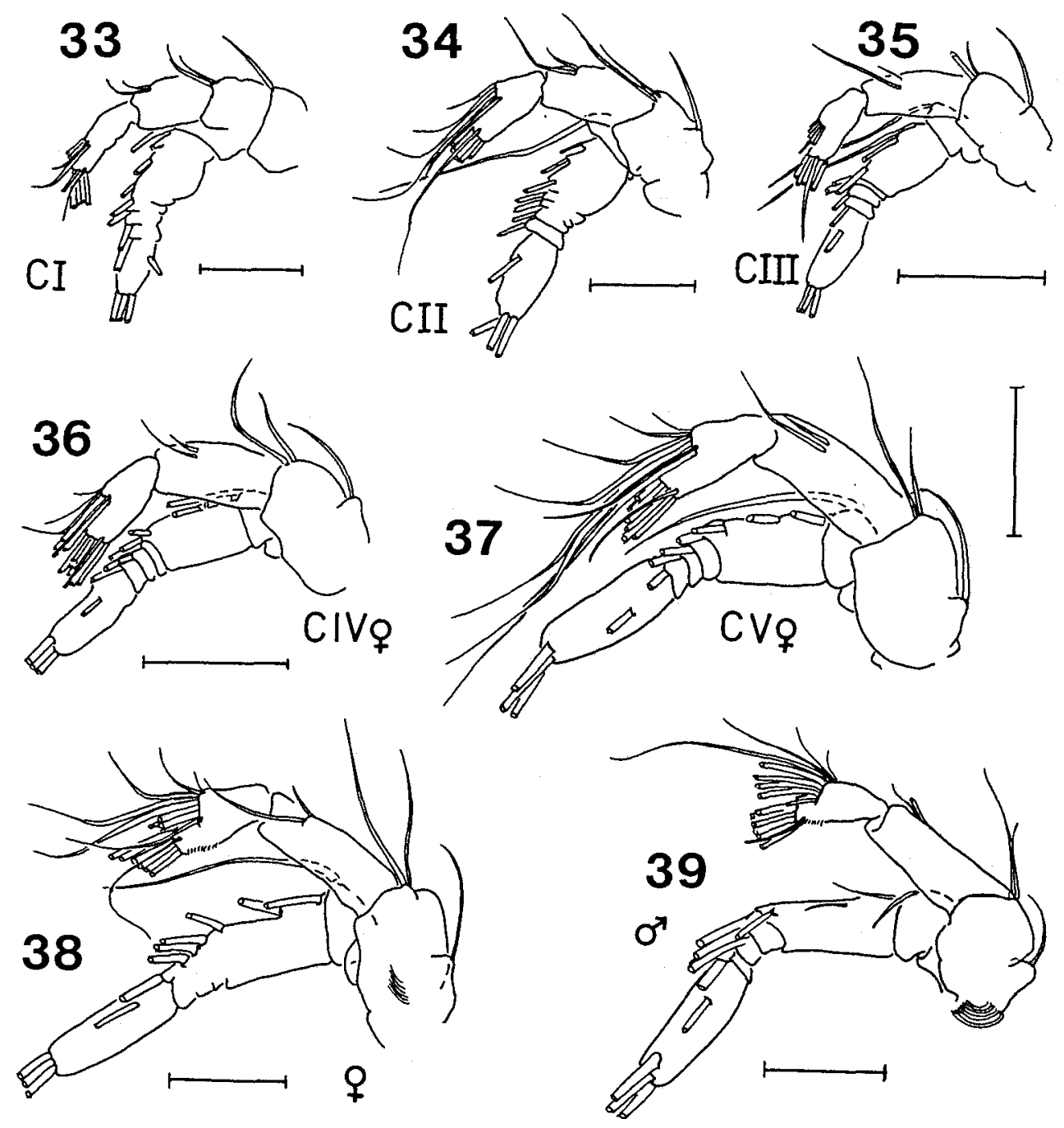

Figs 33-39. Drepanopus forcipatus. Right second antenna, ventral view. Scales. $0.05 \mathrm{~mm}$ : Figs 33 , 34; $0.1 \mathrm{~mm}$ : Figs 35-39

large siliceous ventral tooth is added thus completing the basic set of eight teeth which is maintained throughout the development of the various stages into the adult female. In the adult male, however, the mandible blade is relatively small, its chewing edge narrow and devoid of teeth.

In the first maxilla (Figs 55-62) of copepodid I all segments and lobes present in the adult are already developed. However, the setae at all sites except on the third inner lobe are fewer than in the first maxilla of the adults. During the molts into the various copepodid stages setae are added at various sites. In the adult male, especially the spines on the first inner lobe are relatively weak. 

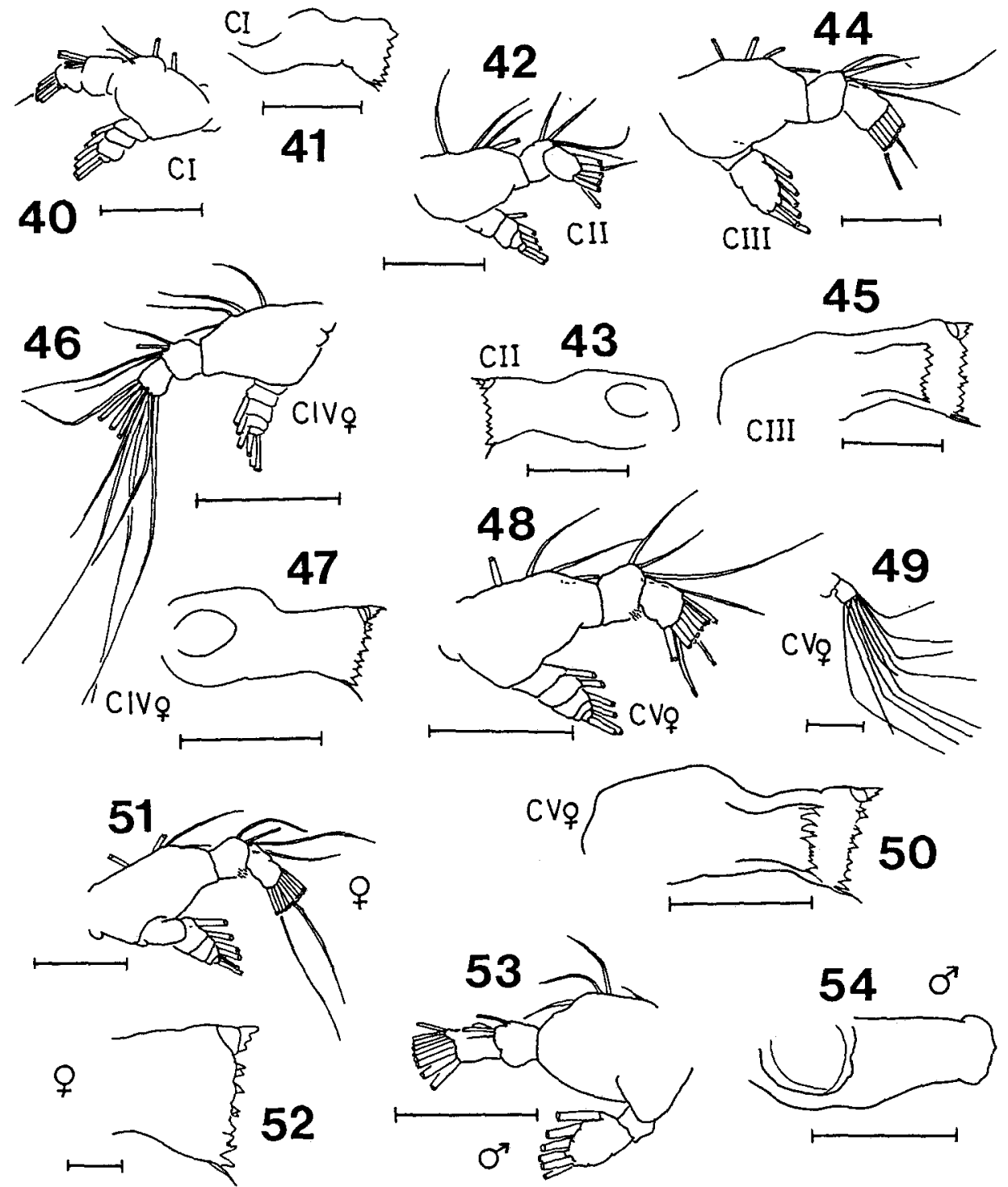

Figs 40-54. Drepanopus forcipatus. Right mandible. Figs 40, 42, 44, 46, 48, 51, 53 palpus; Figs 41, 43, 45, 47, 50, 52, 54 blade; Fig. 49 second endopodal segment from Fig. 48. Scales. 0.05 mm: Figs 40-45;

$0.1 \mathrm{~mm}$ : Figs 46-54

The second maxilla (Figs 63-69), too, exhibits the general morphology of the adult in copepodid I. From copepodid II on, all setae which are present in the adult female are developed. In the adult male the second maxilla is smaller and its setae are weak.

The maxilliped (Figs 70-76) in copepodid I has two basipodal and only one endopodal segments. As late as in copepodid IV, all five endopodal segments of the adult are developed. Setae are added throughout the development of the copepodids. 

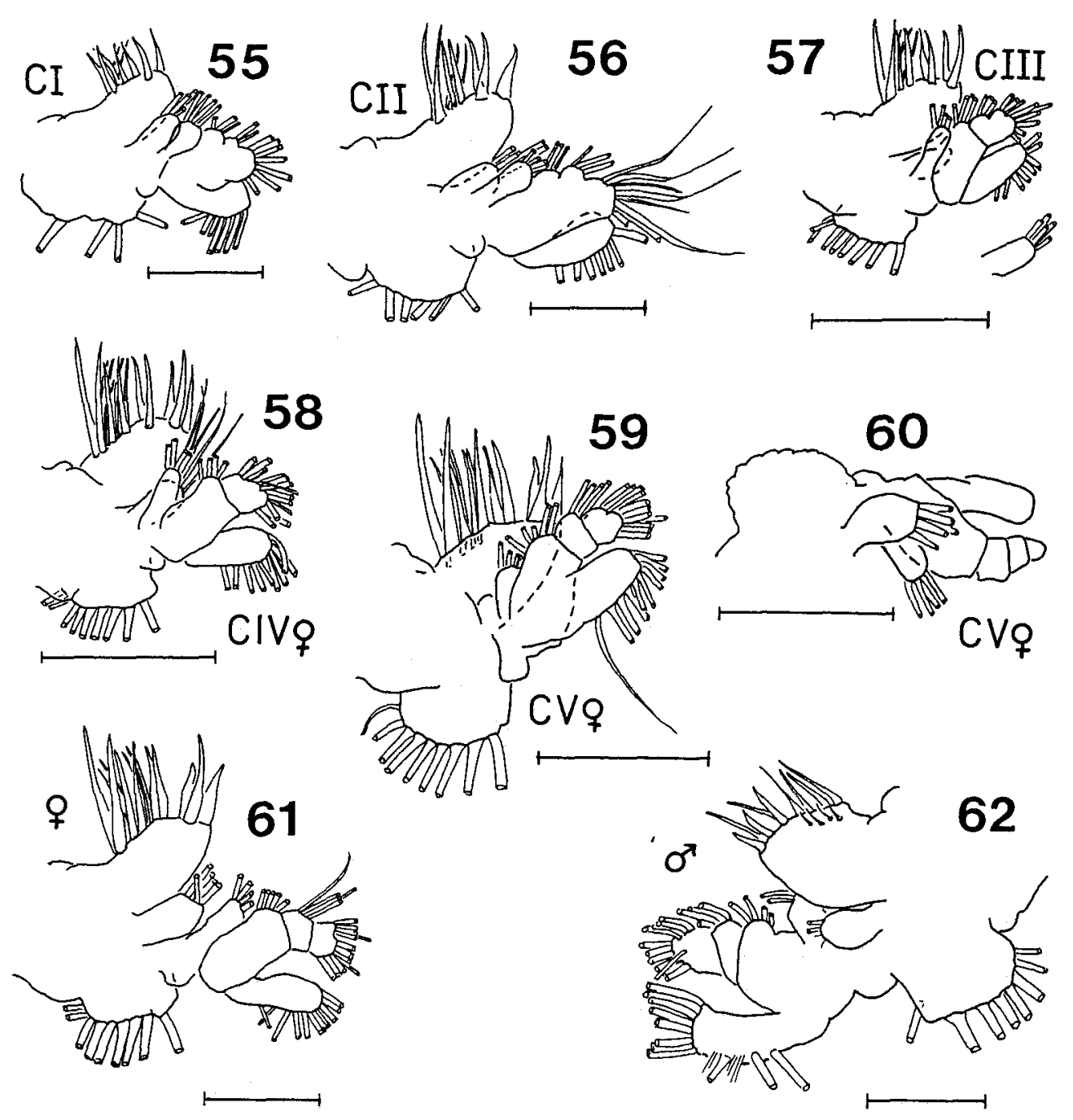

Figs 55-62. Drepanopus forcipatus. Right first maxilla. In Fig. 57 second inner lobe shown separately; Fig. 60 as Fig. 59, different position; Fig. 61: exopod separated to allow full view of lobes. Scales $0.05 \mathrm{~mm}$ : Figs 55, 56, 62; $0.1 \mathrm{~mm}$ : Figs 57-61

Metas some (Table 2). The exopods of the first (Figs 77-83) and second (Figs 84-90) swimming legs attain the three segments of the adult with their respective sets of setae and spines with the molt into copepodid $V$. To the 1 -segmented endopod of the first leg no further segments are added. A second segment is added to the endopod of the second leg in copepodid III, but addition of a further segment is suspended. The incipient third (Fig. 1) and fourth (Fig. 2) legs of copepodids I and II, respectively, have the appearance of a ventral bulge. The incipient fifth leg is hardly noticeable. Both outer and inner rami of the third (Figs 91-96) and fourth (Figs 97-101) legs are completed only in 

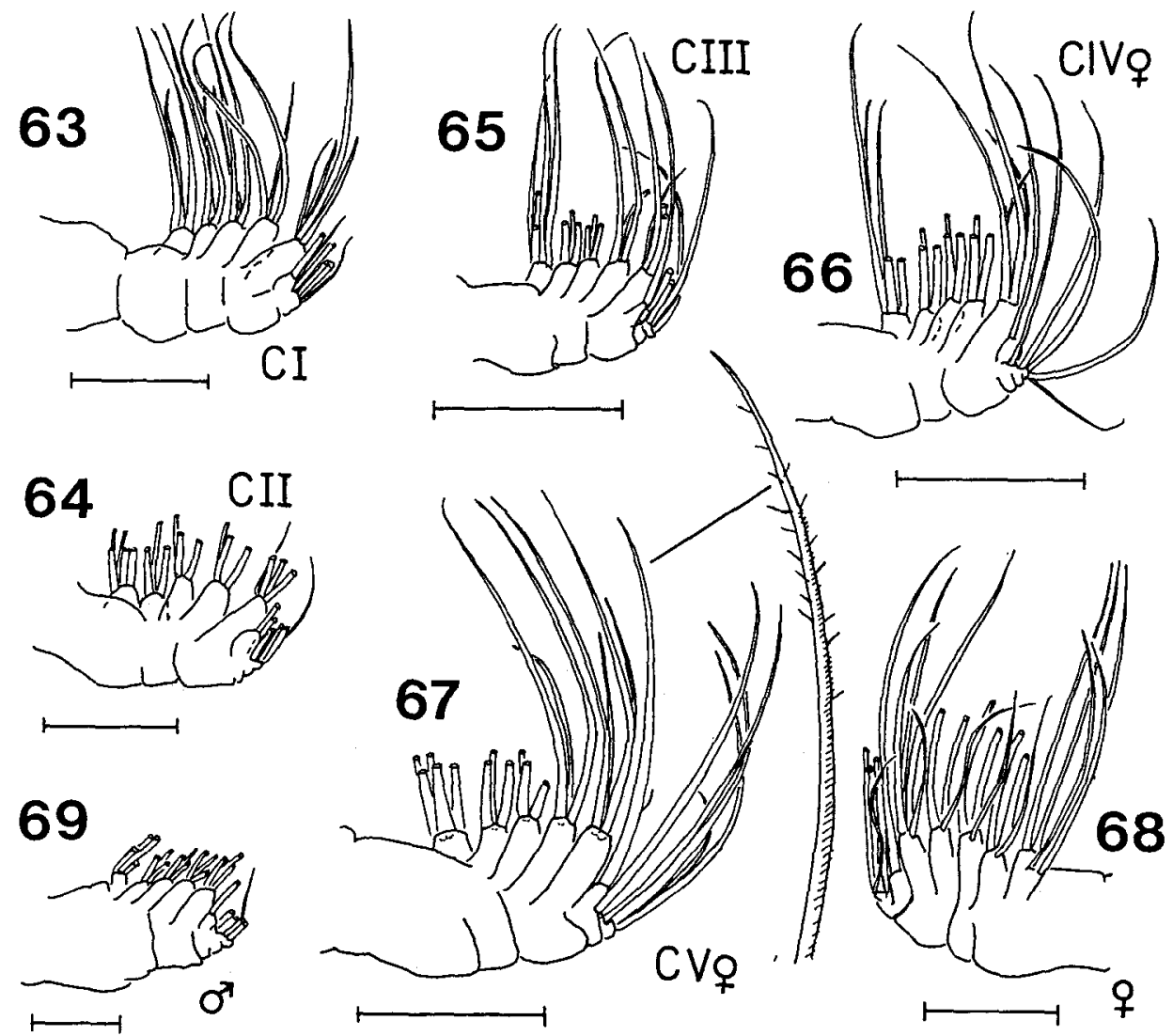

Figs 63-69. Drepanopus forcipatus. Right second maxilla. Scales. $0.05 \mathrm{~mm}$ : Figs 63, 64, 69; $0.1 \mathrm{~mm}$ : Figs 65-68

copepodid V. The seta on the medial margin of the first basipodal segment shows up for the first time on the second leg in copepodid II (Fig. 85), on the third leg in copepodid III (Fig. 92), and on the fourth leg in copepodid IV (Fig. 98). The anterior seta near the medial distal margin of the second basipodal segment of the first leg appears in copepodid II. Sexual dimorphism begins to show in the fifth legs in copepodid IV. The fifth legs of both, males (Figs 103, 105, 107) and females (Figs 102, 104, 106) reach full development only with sexual maturity.

\section{Comparison of copepodids with those of other genera in the family Clausocalanidae}

In the family Clausocalanidae, copepodids have been described for Clausocalanus laticeps, C. brevipes and Ctenocalanus citer by Heron \& Bowman (1971), and, in part, for Pseudocalanus sp. by Oberg (1906), Kraefft (1910) (both as P. elongatus) and Corkett \& 

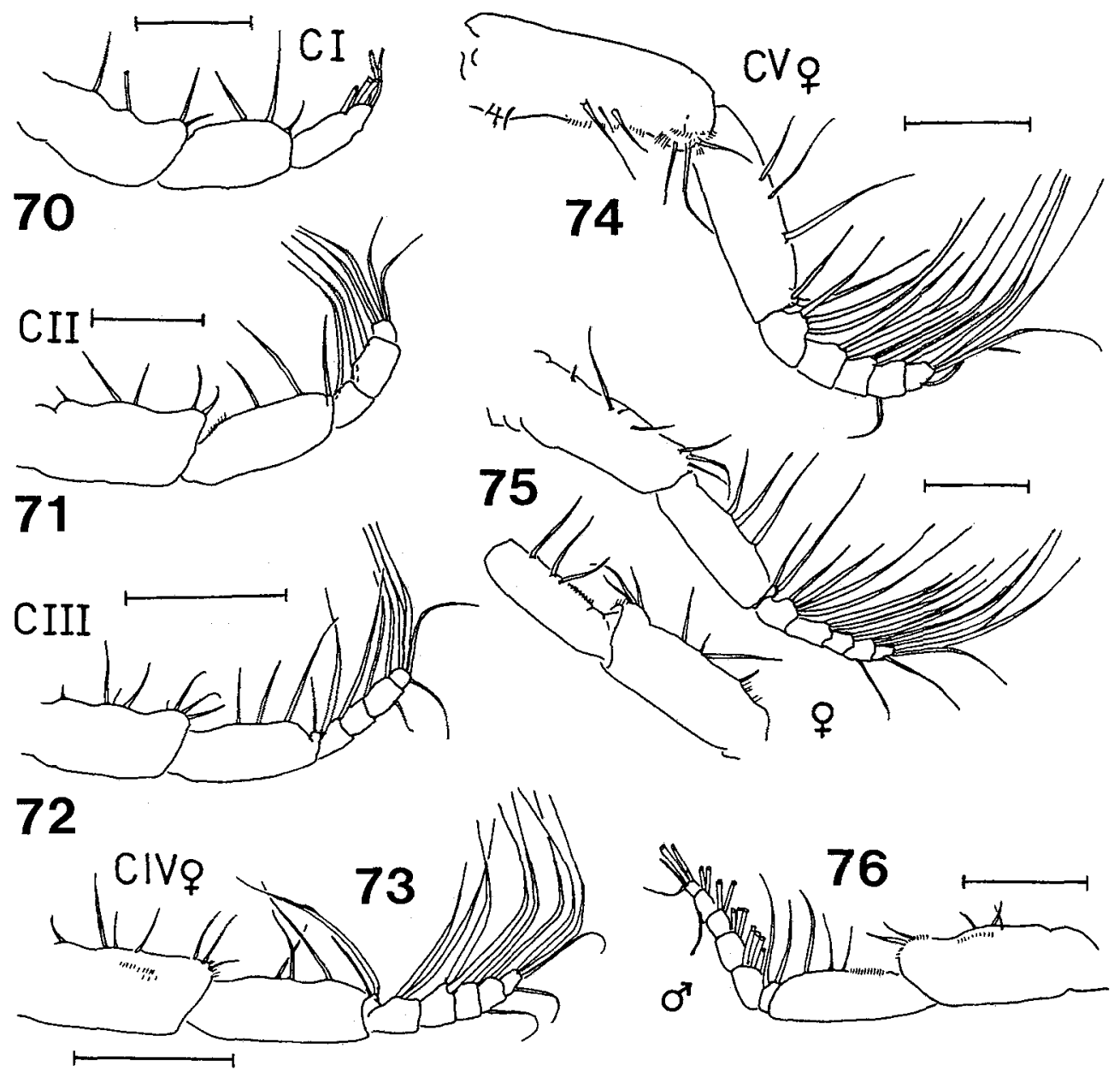

Figs 70-76. Drepanopus forcipatus. Right maxilliped. Fig. 75: first and second basipodal segments also in inner view. Scales. $0.05 \mathrm{~mm}$ : Figs 70, 71; $0.1 \mathrm{~mm}$ : Figs 72-76

McLaren (1978, without specific designation). Corkett and McLaren summarized and discussed nomenclatural and systematic problems in Pseudocalanus. The admirable revision of the genus by Frost (1989) now allows identification of the several species of Pseudocalanus. Specific reference, however, to forms reported and described by previous authors is not always possible as these authors often failed to provide necessary particulars. For the purpose of the present comparison, it is assumed that the morphology of the copepodid stages agrees among the members of the genus; therefore, reference is made here only to Pseudocalanus sp. Development of all above species follows the same

Figs 77-90. Drepanopus forcipatus. Legs, anterior view. Figs 77-81; first pair; Figs 82, 83: right first leg; Fig. 83: exopod also in posterior view; Figs 84-88: second pair; Figs 89, 90: right second leg. Scales. $0.05 \mathrm{~mm}$ : Figs 77, 78, 84; $0.1 \mathrm{~mm}$ : Figs 79-81, 85-88; $0.2 \mathrm{~mm}$ : Figs 82, 83, 89, 90 

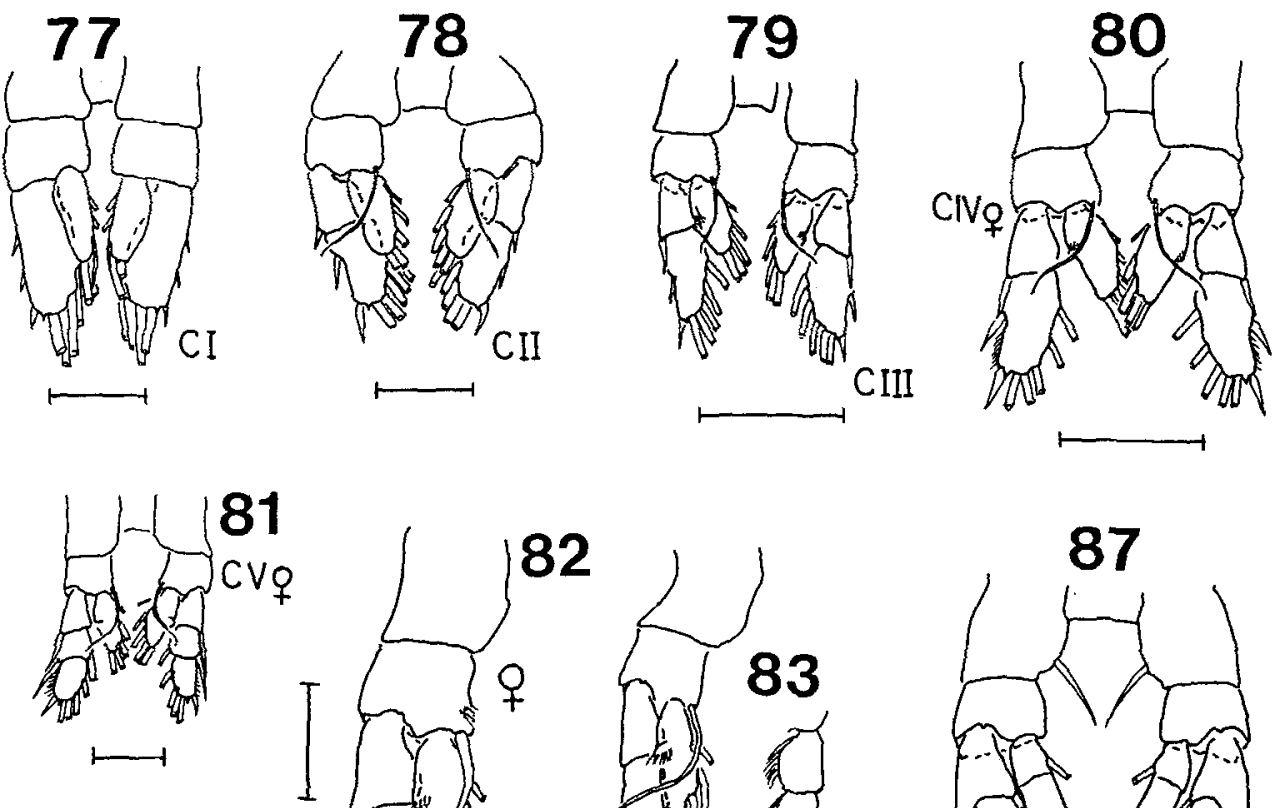

84
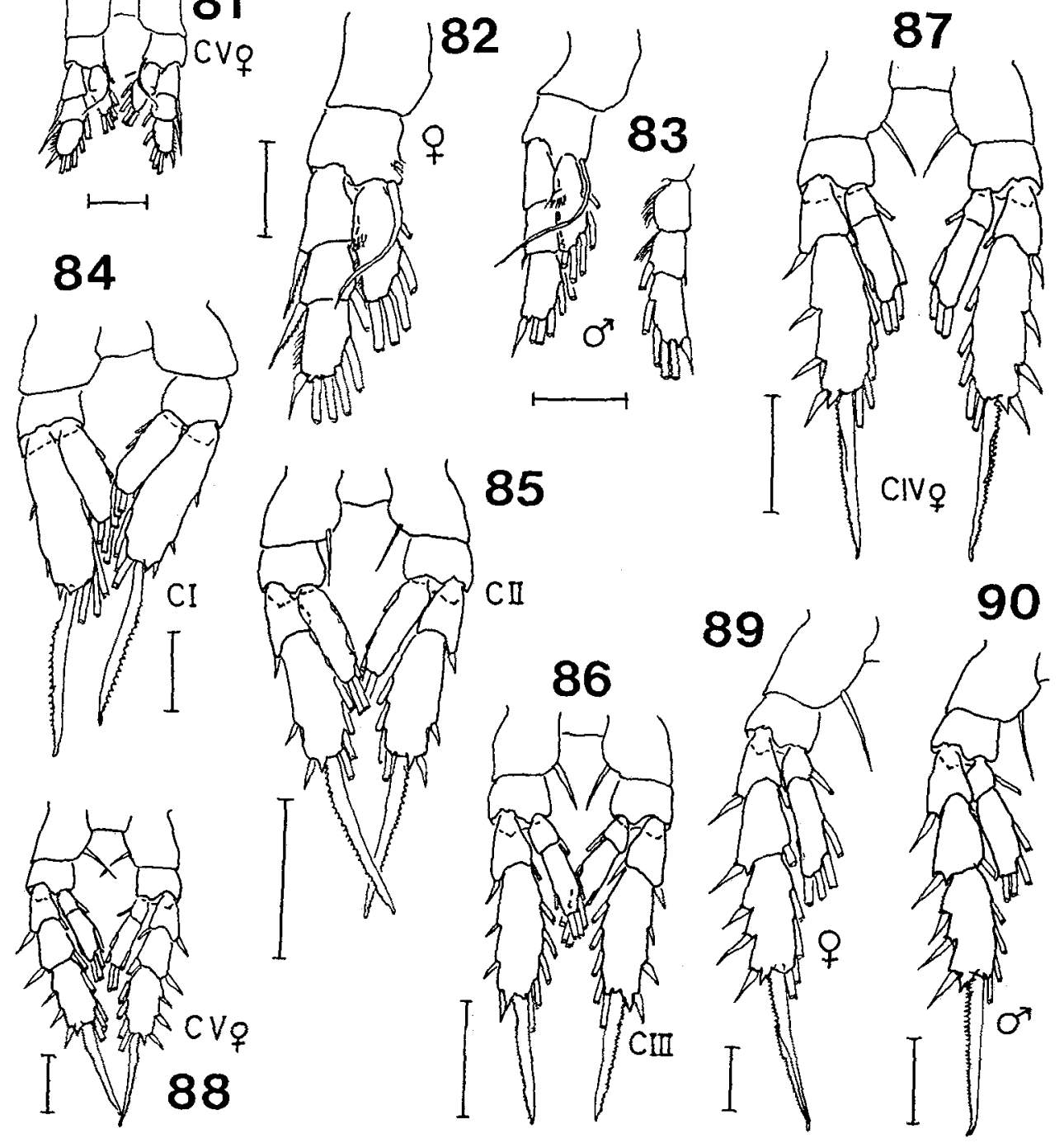
K. Hulsemann
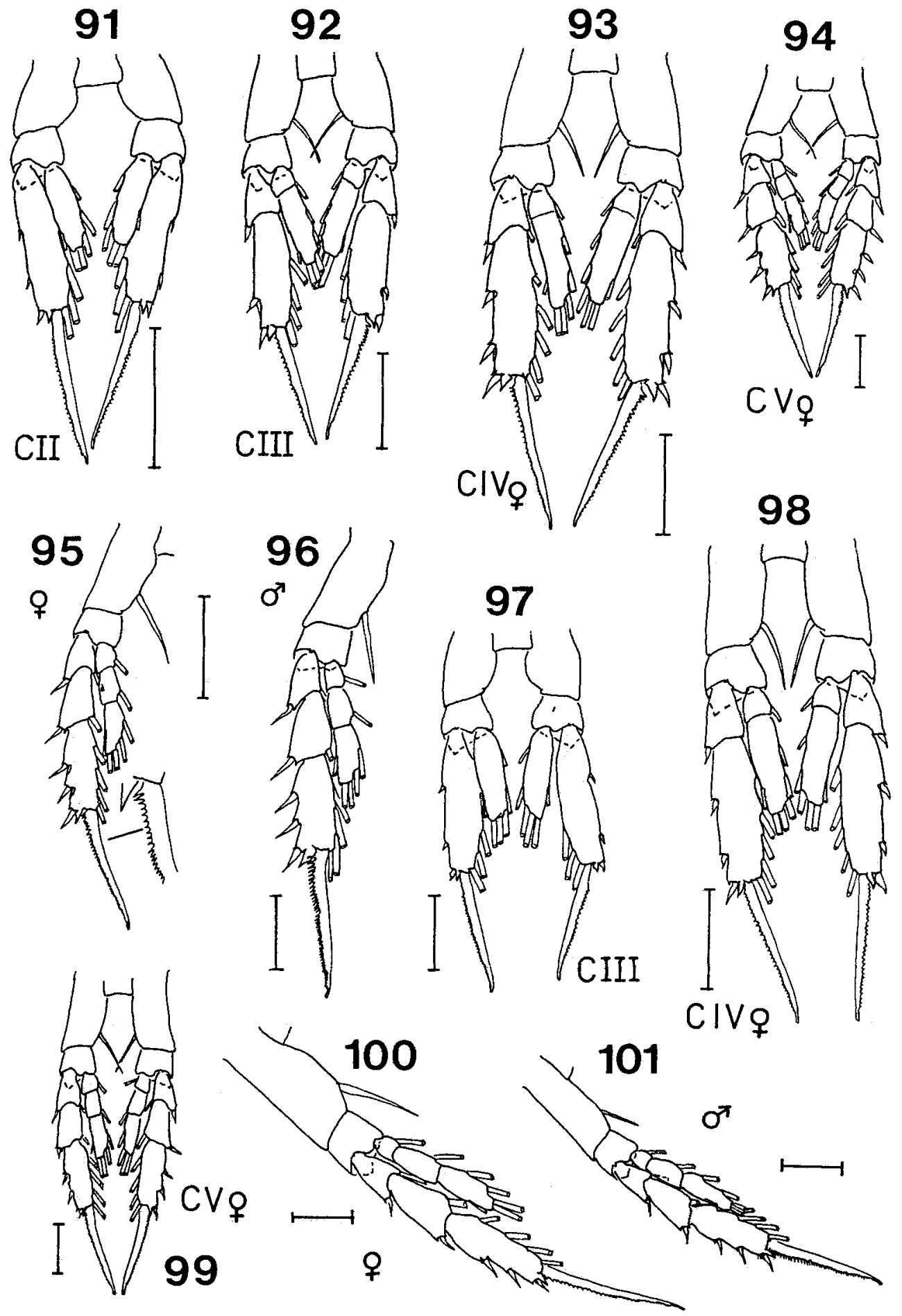

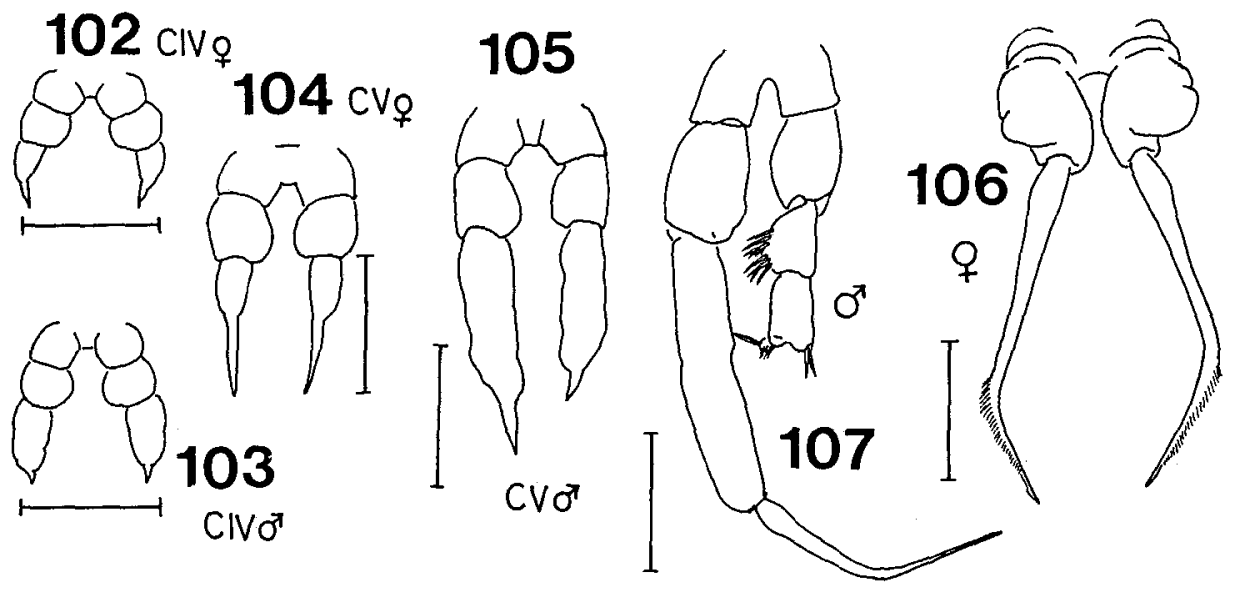

Figs 102-107. Drepanopus forcipatus. Fifth pair of legs. Scales. $0.1 \mathrm{~mm}$

Table 2. Drepanopus forcipatus. Number of ramal segments on legs 1 to 5 in copepodid stages $\mathrm{I}$ to $\mathrm{V}$ and adults. Organization after Ferrari (1988). $\mathrm{i}=$ incipient leg; $1-1=$ reorganized leg with 1-segmented exopod $(\mathrm{Re})$ and 1 -segmented endopod $(\mathrm{Ri})$, etc.; lt. = left; rt. = right

\begin{tabular}{|c|c|c|c|c|c|}
\hline Stage & $\begin{array}{l}\text { Leg } 1 \\
\text { Re-Ri }\end{array}$ & $\begin{array}{l}\text { Leg } 2 \\
\text { Re-Ri }\end{array}$ & $\begin{array}{l}\text { Leg } 3 \\
\text { Re-Ri }\end{array}$ & $\begin{array}{l}\text { Leg } 4 \\
\text { Re-Ri }\end{array}$ & $\begin{array}{l}\text { Leg } 5 \\
\text { Re-Ri }\end{array}$ \\
\hline I & $1-1$ & $1-1$ & $\mathrm{i}$ & & \\
\hline II & $2-1$ & $2-1$ & $1-1$ & $\mathbf{i}$ & \\
\hline III & $2-1$ & $2-2$ & $2-2$ & $1-1$ & $\mathrm{i}$ \\
\hline IV 9,0 & $2-1$ & $2-2$ & $2-2$ & $2-2$ & $1-0$ \\
\hline $\mathrm{V} q, \delta$ & $3-1$ & $3-2$ & $3-3$ & $3-3$ & $1-0$ \\
\hline$q$ & $3-1$ & $3-2$ & $3-3$ & $3-3$ & (1)-0 \\
\hline 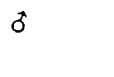 & $3-1$ & $3-2$ & $3-3$ & $3-3$ & $\begin{array}{l}\text { lt. } 3-0 \\
\text { rt. } 1(2)-0\end{array}$ \\
\hline
\end{tabular}

general pattern, although small differences between these species and Drepanopus forcipatus were noticed.

Body

In copepodid I of Drepanopus forcipatus, cephalon and first metasomal segment (ThI) are separated as in Pseudocalanus sp. In copepodid II a fine line separates the cephalon from ThI in $D$. forcipatus. In copepodids III to $\mathrm{V}$ this line of separation is recognizable only dorsally. In adults, cephalon and ThI are completely fused. In Clausocalanus laticeps, C. brevipes and Ctenocalanus citer, cephalon and ThI are fused and remain so through the adult. In the adult Pseudocalanus sp., cephalon and ThI are

Figs 91-101. Drepanopus forcipatus. Legs, anterior view. Figs 91-94: third pair; Figs 95, 96: right third leg; Figs 97-99; fourth pair; Figs 100, 101: right fourth leg. Scales. 0.1 mm: Figs 91-94, 96-101; 
fused; Giesbrecht (1882), however, shows a fine separating line in dorsal view of the male.

Metasomal segments IV and V of $D$. forcipatus are separated in copepodids III to V, and only partly so in adults. Heron \& Bowman (1971) illustrate merely an incipient suture on the apparent posterior metasomal segment of copepodid III in Clausocalanus laticeps, C. brevipes and Ctenocalanus citer and a very weak one in copepodids IV $q$ and IV $\delta$ of Clausocalanus laticeps and in copepodid IV $q$ of Ctenocalanus citer. Stephensen (1913, pl. IV) indicates separation of metasomal segments IV and V-dorsally in lateral view and laterally in dorsal view - in the stage III copepodid of Pseudocalanus sp. Both segments are completely fused in adult females and males of this and the preceding three species.

In Drepanopus forcipatus, rostrum and filaments appear for the first time in copepodid II as in all calanoid copepod species where reported, so also in Pseudocalanus sp. However, Heron \& Bowman (1971) mention a rostrum already in copepodid I in Clausocalanus laticeps and C. brevipes, and rostral filaments in Ctenocalanus citer, even if delicate and difficult to discern. In the adult male of $D$. forcipatus, the rostrum is formed as a median, ventrally protruding knob; this is true for all species of Clausocalanus with the exception of $C$. furcatus (Frost \& Fleminger, 1968), but not for Ctenocalanus citer, Pseudocalanus sp. nor for Drepanopus pectinatus, a close relative of $D$. forcipatus in the Southern Indian Ocean.

The small medial or appendicular seta on both caudal rami inserts ventrad of the medial margin in copepodid I of $D$. forcipatus; it is found at this position in all stages including the adult. In Oberg's rendition (1906) of copepodid I of Pseudocalanus sp. this seta appears to insert dorsally. However, Frost (1989) shows it in all seven species of Pseudocalanus in a ventral position. Caudal setae were not indicated by Heron \& Bowman (1971). In adult Clausocalanus sp., the position of the appendicular seta is dorsal, and in Ctenocalanus sp. ventral of the medial margin.

\section{Appendages}

Cephalos ome. In descriptions of copepodids the free segments of the first antenna are usually counted, beginning with the most proximal segment. Few attempts have been made to homologize segments or armature in the various stages. My numbering of the segments relates to the widely recognized 25 (Giesbrecht, 1892; Fleminger, 1985 ) or 26 (von Vaupel Klein, 1982a) segments, respectively, of adult calanoids. When tracing the several elements of the first antenna through the various copepodid stages, first appearance and position of setae and aesthetascs are most helpful. Segment 2 is composed of three nearly always fused (primitive) segments which are referred to as segments $2 a-c$. The numbering sequence of $1-25(26)$ is here maintained in order to facilitate comparison with existing descriptions of other species (see von Vaupel Klein, 1982a).

Most authors give the number of (free) segments in the first antenna of copepodid I as ten, or occasionally as nine, when the two distal-most segments are fused. The three proximal segments correspond to segments 1 to 3,4 to 9 and 10 to 18 , respectively, of the adult in Drepanopus forcipatus and Pseudocalanus sp. (Oberg, 1906). Heron \& Bowman (1971) report the highest number yet, 13 in copepodid I of Clausocalanus laticeps, $C$. brevipes and Ctenocalanus citer, pointing, though, to the difficulty in determining the exact number of antennal segments in early copepodids. They show two segments in 
place of the "second" and three segments in place of the "third" of the usual three proximal segments. The seven distal segments correspond to segments 19 to 25 of the adult. In the adult $D$. forcipatus male, segments 20 and 21 are fused only on the right side. This fusion is observed on both sides in Clausocalanus species, Ctenocalanus citer, $C$. vanus and Pseudocalanus sp.

Heron \& Bowman (1971) omitted setae and aesthetascs from their descriptions thus precluding further comparison. There are differences in the armament of the first antenna between Drepanopus forcipatus and Pseudocalanus sp. as illustrated by Oberg (1906). In copepodid I, I failed to find a seta on the site of segment 9 of $D$. forcipatus which is present in Pseudocalanus sp,; in the latter, however, aesthetascs are absent from sites on segments 19 and 25, which, in turn, are present in D. forcipatus. In copepodid II one aesthetasc each appears on segments 2, 3 and 9 in $D$. forcipatus while in Pseudocalanus sp. the only aesthetasc shown originates from segment 9 . From copepodid III on, my interpretation of the development of the first antenna differs from Oberg's assignment of several setae to certain precursors in the preceding stage, e.g. his setae "W" (assignable to segment 3), "Sch. 1" (segment 7) and "Sch. 2" (segment 9) in copepodid II are placed by him with segment 7, 9 and 14, respectively, in copepodid III. According to my segment count, in copepodid III of $D$. forcipatus aesthetascs are added on segments 5 and 14, of Pseudocalanus sp., according to Oberg's count, on segments 14 and 18 ; in copepodid IV of $D$. forcipatus on segment 12, of Pseudocalanus sp. on segments 5,12 and 19. At stage IV the total number of aesthetascs present in the adult female of $D$. forcipatus is reached, i.e., on segments $2 b, 3,5,9,12,14,19,25$. Oberg does not show the first antennae of copepodid V nor adult Pseudocalanus sp. When comparing the first antenna of adult Pseudocalanus sp. of Heron (Griffiths \& Frost, 1976) with that of $D$. forcipatus, there is complete agreement in segmentation and number, plaçement and size of setae and aesthetascs between females of both species. Also the first antenna of Pseudocalanus sp. figured by Giesbrecht (1882, as Lucullus acuspes) agrees well except no aesthetascs are shown.

In the adult male of Drepanopus forcipatus, segments 10,11 and 12 are incompletely separated. On segment 8 are two setae and one aesthetasc; segment 10 carries one aesthetasc, segment 11 is naked. In Pseudocalanus sp., segments 10,11 and 12 are shown completely fused. Segment 8 carries only one seta and one aesthetasc; segment 11 appears to carry one aesthetasc whereas segment 10 is naked. I did not detect a minute seta next to the aesthetasc on segment 25 in $D$. forcipatus which is present in Pseudocalanus sp. The armament of the male first antenna of Pseudocalanus sp. in Giesbrecht (1882, as Lucullus acuspes) is incomplete.

It is unusual for a feature that made its appearance during ontogeny, such as the aethetasc shown by Oberg (1906) on segment 18 in copepodid III, to disappear again later on. Aesthetascs are often difficult to discern; therefore, differences seen between Oberg's drawings of Pseudocalanus sp. and my specimens of Drepanopus forcipatus may or may not be real.

Segmentation and armature of the second antenna through the maxilliped from copepodid I through the adult Drepanopus forcipatus is nearly identical to those reported by Heron \& Bowman (1971) for Clausocalanus laticeps, C. brevipes and Ctenocalanus citer. The differences noticed between $D$. forcipatus and the three species above are minor and concern the first maxilla and the maxilliped: There are 5 setae on the first 
endopodal segment of the first maxilla in the adult female of $D$. forcipatus instead of only 4 setae as in the other species. The first basal segment (coxa) of the maxilliped of $D$. forcipatus carries 4 setae in copepodid I, 5 setae in copepodid II, and 7 setae from copepodid III to the adult female whereas there are 6, 7 and 9 setae, respectively, in the corresponding stages of Clausocalanus laticeps, $C$. brevipes and Ctenocalanus citer. Indeed, near the proximal seta on this segment in $D$. forcipatus one to several bristles are found which may or may not be vestigial setae; I prefer here not to include them in the setae count. In the adult female of $D$. forcipatus the number of setae on endopodal segments 2 to 4 is $3,2,3$ compared to $4,3,4$, respectively, on the same segments of the other three species.

Frost \& Fleminger (1968) show in their illustrations of the adult Clausocalanus mastigophorus female one additional segment and one additional seta in the exopod of the second antenna and one extra segment in the maxilliped, a discrepancy that is discussed by Heron \& Bowman (1971).

Postm axillipedal legs. Among the incipient legs 3, 4 and 5 in copepodids I, II and III, respectively, leg 5 is markedly smaller than the others in Drepanopus forcipatus, reflecting the much smaller size of this leg in later stages. Oberg (1906) shows

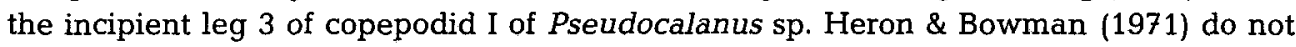
indicate the formation of incipient legs 3 to 5 in Clausocalanus spp. and Ctenocalanus citer. However, their figures offer themselves to the supposition that these authors interpreted the apparent ventral bulges in places of incipient legs as part of the respective last metasomal segments in copepodids I, II (and III).

The first appearance in Drepanopus forcipatus of the various segments of the swimming legs 1 to 4 and their armament of setae and/or spines (Table 2) are identical to those which Clausocalanus laticeps, $C$. brevipes and Ctenocalanus citer exhibit during their development. Deviating from the common pattern of Ferrari (1988) in which segment additions take place in copepods, the endopods of swimming legs 1 and 2 of these species fail to attain the complement of three segments in the adult: In leg 1, serial addition of one segment is suppressed during molt from copepodid I to copepodid II, and simultaneous addition suspended during molt from copepodid IV to copepodid V. In leg 2 , serial addition of one segment during molt from copepodid I to copepodid II is delayed to the subsequent molt to copepodid III, and, as in leg 1, simultaneous addition suspended during molt from copepodid IV to copepodid V. The identical patterns of swimming leg development among the representatives of the genera Drepanopus, Clausocalanus and Ctenocalanus fit the observation of Ferrari that such patterns are often uniform within a family.

In Drepanopus forcipatus, an inner seta is present on the first basipodal segment of the fourth leg from copepodid stage IV on. This seta is also found in adult Pseudocalanus sp., but lacking in Clausocalanus sp. and Ctenocalanus sp.

During molt from copepodid III to copepodid IV, partial reorganization of the incipient fifth legs (primary leg buds) in both sexes of Drepanopus forcipatus gives rise to legs in which only exopods are formed.

In the fifth legs of copepodid IV, the left and right proximal basipodal segments and the coupler, or interpodal bar, are separated in Drepanopus forcipatus, but fused in Clausocalanus spp., Ctenocalanus citer (Heron \& Bowman, 1971) and Pseudocalanus sp. (Kraefft, 1910) as in subsequent stages. 
The spine-like process with its bulbous base in the fifth leg of the adult female of Drepanopus forcipatus (Fig. 106) is understood as modified exopod with its terminal spine (Hulsemann, 1985). In Ferrari's (1988) terminology, the female fifth legs develop by suppression of both serial additions to the outer ramus, followed by transformation of the outer ramus with its terminal spine. The fifth legs of the females of Clausocalanus laticeps and $C$. brevipes change relatively little after partial reorganization in copepodid IV, since no further transformation takes place after suppression of both serial additions to the exopod. In females of Ctenocalanus citer only a vestigial fifth leg is formed; it consists of one or two segments or may be absent. The female of Pseudocalanus sp. suppresses development of fifth legs with few exceptions (Mrázek, 1902).

In the male fifth leg of Drepanopus forcipatus, the 3-segmented left ramus develops by double addition of segments during the molt from copepodid $\mathrm{V}$ to the adult. In the formation of the right ramus the first serial addition is delayed during molt from copepodid IV to copepodid $V_{\text {; }}$ instead, it occurs in the molt from copepodid $V$ to the adult. At the same time, the expected second serial addition of one segment, that would separate the first exopodal segment from the second, is suppressed. The distal spine-like process with its bulbous base in the adult (Fig. 107) is here considered to be derived from the theoretical third exopodal segment fused with its terminal spine.

No endopods are formed in the fifth legs of either sex in Drepanopus forcipatus; the same is the case in the congener $D$. bungei Sars (Sars, 1898; Jashnov, 1927). However, the males of $D$. pectinatus Brady and $D$. bispinosus Bayly do develop one-segmented, if little differentiated, endopods (Bayly, 1982).

To the partially reorganized fifth legs of copepodid IV males of Clausocalanus laticeps, $C$. brevipes and Ctenocalanus citer two serial additions are made only on the left ramus. No additions are made to the right leg. The latter nearly completely merges with the first basal segment of the left leg in the adult C. laticeps; in C. brevipes a small terminal segment with a short distal seta is maintained. Also Ctenocalanus citer retains one free segment. The adult males of C. campaneri Almeida Prado-Por, C. tageae Almeida Prado-Por and various populations reported under the name $C$. vanus Giesbrecht lack a right fifth leg. In Pseudocalanus (Kraefft, 1910) the distal segment of the fifth legs of the copepodid IV male is slenderer than in D. forcipatus. The left side develops through two serial additions. The right side makes one serial addition during molt from copepodid IV to copepodid V, but suppresses the second serial addition during molt to the adult. In the adult, the two basal segments of the right leg are incompletely fused: they are shown separated by Giesbrecht in 1882. In 1892, Giesbrecht shows incomplete fusion of two segments also in the exopod.

\section{Integumental pore pattern}

The integument of copepods bears a variety of integumental organs. These are small, localized organs involving a perforation of the integument (von Vaupel Klein, 1982b), as sensilla and underlying glands with excretory ducts, that are basically distributed in bilaterally symmetrical patterns. These patterns, or signatures, have been shown to be of taxonomic value in the distinction of populations and higher categories up to the superfamilial level (Fleminger, 1973; Fleminger \& Hulsemann, 1987; Mauchline, 1988; Hulsemann \& Fleminger, 1990). Mauchline distinguishes two suites of pores in the 
integumental pore patterns of calanoid copepods. The first suite consists of the basic pattern traceable throughout the Calanoida with derivable modifications. It is represented by the pattern of the superfamily and amplified in that of the family. It is representative of phylogenetic trends within the order. The second suite consists of complexes of pores that are formed at the generic and specific levels and indicate specialization within these categories.

Mauchline (1988) restricted his investigation to the patterns in the five metasomal segments of females. For the Clausocalanidae he presented the signatures of three genera: Pseudocalanus Boeck, 1882, Clausocalanus Giesbrecht, 1888, and Farrania Sars, 1920 , and a provisional signature for the family. Here the signatures of Drepanopus Brady, 1883 and Ctenocalanus Giesbrecht, 1888 are added (Figs 108, 109).

Ten females of Drepanopus forcipatus ( 5 each from William Scoresby Station WS42 and Walther Herwig 36 Station 300) and 5 females each of D. pectinatus (Heard Island) and Ctenocalanus sp. (Walther Herwig 36 Station 321) were cleared of all internal tissues and stained as described by Fleminger (1973). The holes in the integument, visible after treatment at the sites of integumental organs, are mainly of two sizes. Large pores are left by hair sensilla and small pores by the exits of underlying glands. Various structures occupying the sites of the (future) pores were described by Fleminger (1973) and von Vaupel Klein (1982b). I follow Mauchline (1988) in the designation and use of symbols for the pores: large pores (here of $2 \mu \mathrm{m}$ diameter) and small pores (here of $1 \mu \mathrm{m}$ diameter), shown as large and small dots, respectively.

The pore signature of the genus Drepanopus (Fig. 108) was derived from those of $D$. pectinatus and $D$. forcipatus. Divergent from the pattern in common, $D$. forcipatus has in the paired anterior lateral area of metasomal segment II one site more than $D$. pectinatus, in the corresponding area of metasomal segment III two sites more, and between the median complex and the paired dorsal complexes of the same segment one site more. In contrast, two additional sites apparently associated with the paired large pores in the median complex of segment II and three additional sites near the posterior margin of fused segments IV $\sim \mathrm{V}$ are occupied two to three times in the five $D$. pectinatus females examined. Variation between individuals was negligible in either species.

For many decades following its description, Ctenocalanus was considered a monotypic but widely distributed genus. More recently, three species with restricted ranges have been added. Bjornberg (1982) reported the presence of two further forms from off Brazil referring to them as $C$. vanus sensu lato. I found specimens of an undescribed Ctenocalanus species in plankton samples collected during FRV Walther Herwig cruise 36 on the inner Argentine shelf. These copepods may belong to one of Bjornberg's forms. The specimens examined here for their pore signatures are therefore referred to only as Ctenocalanus sp.

The pore signature of Ctenocalanus sp. (Fig. 109) surprises with its profusion of small pores not seen in the other four genera, viz Pseudocalanus, Clausocalanus, Farrania, and Drepanopus. The basic pattern of the large pores, that is shared with these genera, stands out against this background of small pores. Some variation in size among the small pores ( $\leq 1 \mu \mathrm{m}$ diameter) was noticed; however, because of the minuteness of the differences they were not systematically pursued. Bilateral symmetry in the distribution of the small pores appears not to be given. Also, attempts at homologization of these sites between specimens were similarly evasive. Therefore, the pattern recorded of only one of the 

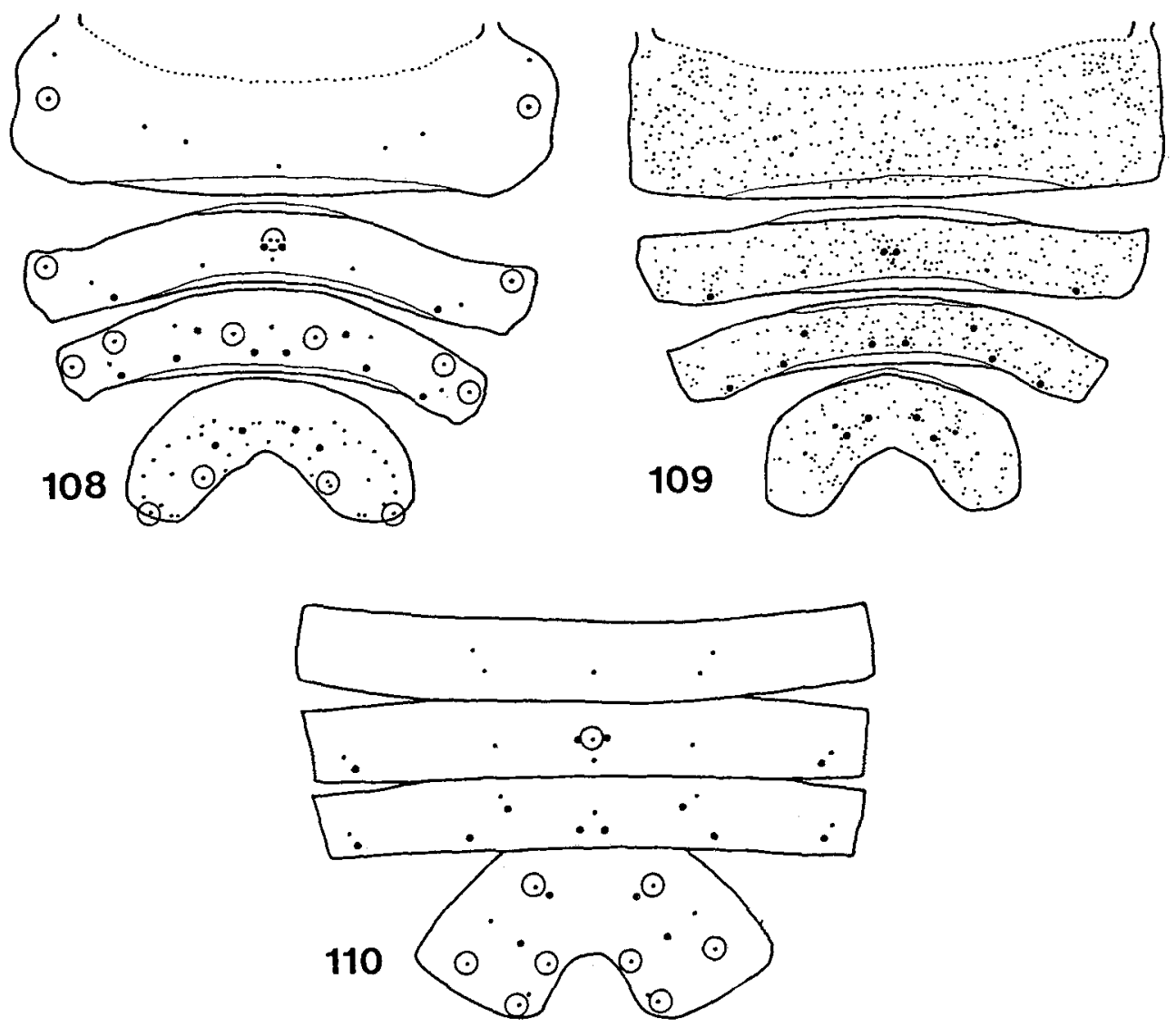

Figs 108-110. Metasomal segments of copepod female spread out flat with ventral regions and swimming legs removed. Pores at sites of integumental organs after treatment in hot potassium hydroxide are shown enlarged. Large and small dots represent large and small pores, respectively. Fig. 108: pore pattern of the genus Drepanopus; plain dots: $100 \%$ presence; ringed dots: presence in $50 \%$ or more of the species examined. Fig. 109: Ctenocalanus sp. Fig. 110: family Clausocalanidae; plain dots: presence in all $l_{i}$ ringed dots: presence in $50 \%$ or more of the genera used

females is here presented. It is possible to assign one pore from this abundance to each site of the familial pore pattern that was derived from the patterns of the other four genera; whether or not these sites are truly homologous remains to be established.

A familial signature for the Clausocalanidae (Fig. 110) constructed from the signatures of the four genera Pseudocalanus, Clausocalanus, Farrania and Drepanopus largely agrees with the provisional signature Mauchline (1988) produced. Resulting modifications are: the two median sites in metasomal segment I and the two dorsal sites in metasomal II of less than $100 \%$ occurrence fall below the $50 \%$ limit; the anterior site on the median line in metasomal segment II falls below the $100 \%$ occurrence. In contrast, four pairs of sites move above the $50 \%$ limit in the fused metasomal segments IV $\sim \mathrm{V}$. The 
paired site of the median complex in metasomal segment III is occupied by two large pores in Drepanopus and Ctenocalanus, as in Pseudocalanus, but by two small pores in Clausocalanus and Farrania. The pattern of Ctenocalanus spp. fully agrees with this modified familial signature if, as discussed above, homology of all sites is assumed.

\section{DISCUSSION}

\section{General pattern}

The first copepodid is composed of a cephalosome, four (or three) free segments, and an anal segment carrying the caudal rami. In calanoid copepods, the apparent major body division, or functional division (Boxshall, 1985), between prosome and urosome is located between the third and fourth free segment in copepodid I, between the fourth and fifth in copepodid II, and between the fifth and sixth in copepodid III. Thus, the apparent urosome continues to be comprised of the anal plus one further segment. The latter becomes incorporated into the set of metasomal segments, anterior to the major body division, during the molts into copepodid II and III, respectively, as the newly formed segment assumes the position of its predecessor. From copepodid III on, the segment that is added during each subsequent molt, i.e. into copepodid IV to the adult, stays in the urosome, i.e. posterior to the articulation (Fig. 111). Consequently, the position of the

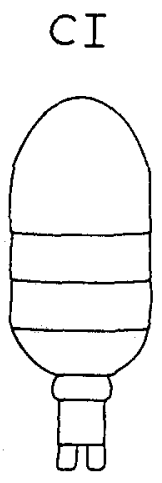

111
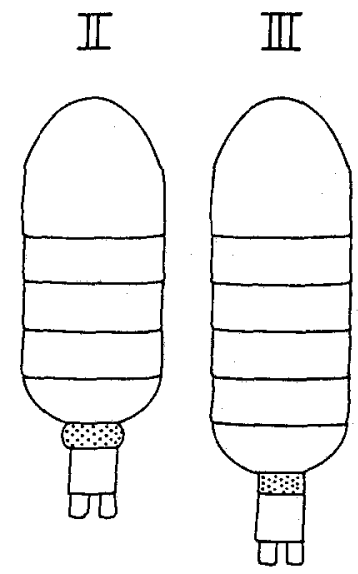
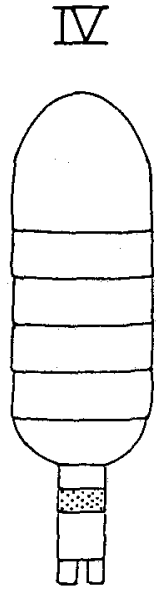

V

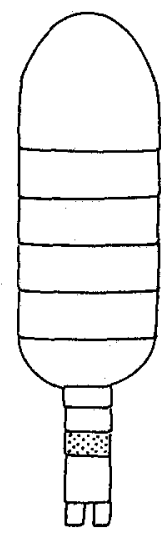

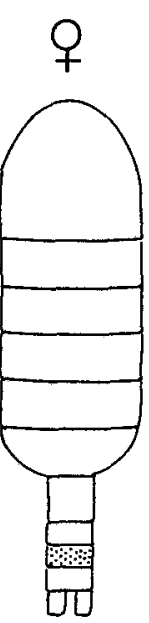

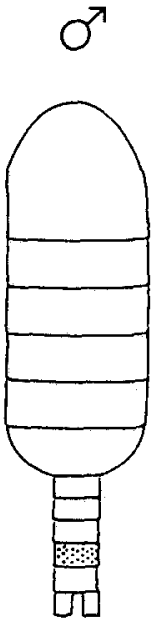

Fig. 111. Copepodid stages I to $V$, adults, schematic. At each stage, stippling marks the most recent segment addition

body articulation remains immediately behind the fifth metasomal segment. Boxshall (1985) drew attention to the absence of a highly differentiated joint in copepodid I and to the fact that the joints between the third and fourth free segments and between the fourth and the anal segments are basic telescoping joints. He suggested that the specialized function of the urosome in locomotion may not yet be acquired at that stage. 
Among the six pairs of appendages of the cephalosome, the mandible blade and second maxilla are changed least. In copepodid $I$, they differ only slightly from those of the subsequent stage at which they already attain the appearance of those of the adult female. The greatest transformation is undergone by the first antenna. Beginning with the molt from copepodid II, new segments are produced in the proximal region of the first antenna (Claus, 1893, p. 255). The new segments are generated from proximal portions of existing segments. The complement of segments typical for the adult female is reached at stage IV, so is the number of aesthetascs. The last setae are added in stage $V$, mainly in the proximal segments. In the male, first antenna segments $1 \sim 2$ and right $20 \sim 21$ fuse, whereas segment 10 fuses incompletely with $8 \sim 9$ during the molt from stage $V$ to the adult. In the areas of fusion, reduction of the number of setae takes place. Additional aesthetascs are produced on segments $1-10,13,15-18,22$, and 23.

Incipient legs 3, 4, and 5 make their appearances in copepodids I, II, and III, respectively. The incipient legs are little differentiated and probably not suited to function in locomotion.

\section{Pattern of segment addition}

In copepodids, segments are added at the various stages by transverse division of an existing segment. Lengthening of the segment in one molt precedes its division in a subsequent molt. Physiological processes and morphological changes taking place in the tissue that is enclosed by the exoskeleton have been described by Passano (1960) mainly for decapod crustaceans. The present study was restricted to changes in copepodid outer morphology. The newly formed segment arises from the proximal portion of the dividing segment. The distal portion may again increase in length proximally and form another segment during a following molt.

In the urosome, a similar generating segment is the anal segment which, in fact, produces five segments in as many molts (Giesbrecht, 1913) (Fig. 111). Consequently, the anal segment is the oldest, and the urosomal segment 4 of traditional count is the youngest.

Beginning with copepodid $I$, the proximal (three) free segments of the first antenna generate new segments serially by a comparable process: lengthening and subsequent constriction of proximal portions of existing segments. Distal portions of antennal segments do not produce new segments. Therefore, a seta near the distal end of an antennal segment in early copepodids is indicative of the distal segment in the respective unit of still undivided future segments.

Similarly, the exopodal as well as the endopodal segment of the reorganized swimming leg produce two subsequent proximal segments (Conover, 1965; Hulsemann \& Fleminger, 1975). Ramal segment 1 is thus the second, segment 2 the youngest, and segment 3 the oldest. Formation of one or both proximal segments may be suppressed.

\section{Affinities in pore signatures}

The pore signature of Pseudocalanus (see Mauchline, 1988) is the simplest of the generic signatures composing the pattern of the family Clausocalanidae (Fig. 110). It agrees nearly completely with the familial signature in the first three metasomal segments, but it has fewer pores in the fused segments IV $\sim \mathrm{V}$. The generic signature in 
segments I to III of Drepanopus (Fig. 108) bears great similarity to that of Pseudocalanus; segments IV $\sim V$, however, yield a second suite of pores, a considerably larger number of pores than any of the three genera examined by Mauchline. He found evidence of a second suite of pores in the genus Clausocalanus, mainly in the paired anterior lateral areas of metasomal segments I to III, but not in Pseudocalanus and Farrania. Ctenocalanus stands apart on the grounds of the huge number of small pores that are distributed seemingly at random over the metasomal segments (Fig. 109). This is the highest number of additional small pores reported so far for Calanoid copepods.

The Clausocalanoidea are the most derived superfamily in the monophyletic arrangement of calanoid copepods of Park (1986). They and the closely allied Spinocalanoidea possess two mid-line pores in the median complex of metasomal segment II (Mauchline, 1988). All families studied by Mauchline belonging to the two superfamilies had both pores except the Euchaetidae, in which family the anterior pore is lacking. In the remaining superfamilies, either this anterior site or both mid-line sites are not occupied. A further divergence is here presented with the patterns in the genus Drepanopus, which also lack the anterior mid-line pore. Instead, there is a pair of small pores in the median complex (Fig. 108). The pair of small pores was present in all five specimens of $D$. pectinatus examined and in three of five $D$. forcipatus from South Georgia, but in none of the five $D$. forcipatus from the Argentine shelf. - It appears that Ctenocalanus sp. agrees in this respect with the familial pattern presented by Mauchline.

\section{Further notes on the genus Drepanopus}

Identity of specimens of Tanaka (1964). Bayly (1982) pointed out that the female Drepanopus pectinatus Brady, illustrated by Tanaka (1964, Pl. I, as Drepanopsis), can be diagnosed as that species and distinguished from $D$. bispinosus Bayly by the arrangement of the facial spinules on the endopod of the first leg. Further agreement of Tanaka's figures with $D$. pectinatus, in contradistinction to $D$. bispinosus, show (1) a more shouldered dorsal outline of the anterior body; (2) a relatively narrower anterior portion of the genital segment in dorsal view (length: width ratio 1.70; in two specimens of $D$. bispinosus $1.36,1.40)$; (3) a relatively short first antenna reaching about the middle of the genital segment (the last three segments are missing in Tanaka's figure), in $D$. bispinosus it reaches the anal segment; (4) a strongly curved terminal spine on the fifth leg.

Tanaka confirmed (in litt.) Bayly's (1982) and Hulsemann's (1985) supposition that the male of which he drew the fifth leg (PI. I, Fig. e) was provided by Dr. Nemoto from the Kerguelen "Whaling Ground".

It is thus quite clear that the specimens depicted by Tanaka are $D$. pectinatus. I am inclined to the view that the female is also from the aforementioned Kerguelen sample. It nevertheless remains open whether the record of the females from his station $16\left(67^{\circ} 21^{\prime}\right.$ $\mathrm{S}, 39^{\circ} 59^{\prime} \mathrm{E}$ ) represents an extension of the known range of $D$. pectinatus or of $D$. bispinosus (see Bayly, 1982).

Record of Chojnacki \& Wegleńska (1984). Drepanopus forcipatus is an inhabitant of coastal and shelf waters around southern South America, including the Falkland Islands, and off South Georgia. Hulsemann (1985) noted statistically significant differences in mean length ratios in the genital segment between females of the 
populations of the two regions and suggested that the Antarctic Convergence presently functioned as an effective barrier to cross-breeding between the populations. Chojnacki \& Wegleńska (1984) reported the occurrence of Drepanopus pectinatus in Antarctic coastal water of King George Island, South Shetlands. The literature referred to by these authors and the locality suggest that their specimens do not belong to this species, which is restricted to neritic waters around Crozet, Kerguelen and Heard Islands in the Indian Ocean sector of the Antarctic (Hulsemann, 1985). Chojnacki \& Wȩgleńska's find may constitute an extension of the known range of $D$. forcipatus or prove the presence of $D$. bispinosus beyond the type locality, i.e. on the coast of Antarctica at $78^{\circ} \mathrm{E}$. Unfortunately, I did not succeed in obtaining specimens which could confirm, or disprove, either possibility.

Additional records from the South American Pacific coast. Hirakawa \& Zama (1985) reported Drepanopus forcipatus as dominant copepod species from southern Chilean coastal waters at about $46^{\circ} \mathrm{S}$, and Marin \& Antezana (1985) show its occurrence near $50^{\circ} \mathrm{S}$, thus adding to the few Pacific records of this species (see Hulsemann, 1985).

In my comparison of Drepanopus forcipatus and D. pectinatus (1985), the base of the second antenna in the male of the latter species was said to be naked. Contrary to this statement, the base of the second antenna in the male of $D$. pectinatus does carry a row of curved spines proximally on its inner side. The same is true for the male of $D$. bispinosus.

Acknowledgements. It is my pleasure to thank Dr. H. S. J. Roe, Institute of Oceanographic Sciences, Wormley, England, for the specimens from the Discovery Collections; Dr. I. A. E. Bayly, Monash University, Clayton, Victoria, Australia, for the paratypes of Drepanopus bispinosus; Dr. H. Schulz, Federal Research Centre for Fisheries, Hamburg, Federal Republic of Germany, for the collection from FRV Walther Herwig cruise 36; and Dr. W. Vervoort, formerly of Rijksmuseum van Natuurlijke Historie, Leiden, The Netherlands, for the sample from Heard Ísland of the Australian National Antarctic Research Expeditions.

\section{LITERATURE CITED}

Bayly, I. A. E., 1982. The genus Drepanopus (Copepoda: Calanoida): a review of species in Antarctic and Sub-Antarctic waters, with a description of $D$. bispinosus, sp. n. - Aust. J. mar. Freshwat. Res. $33,161-172$.

Bjornberg, T. K. S., 1982. Revisāo da distribução dos gêneros Paracalanus, Clausocalanus e Ctenocalanus (Copepoda, Crustacea) ao largo do Brasil. - Bolm Inst. Oceanogr., S. Paulo 29, 65-68.

Boxshall, G. A., 1985. The comparative anatomy of two copepods, a predatory calanoid and a particle-feeding mormonilloid. - Phil. Trans. R. Soc. Lond. (B) 311, 303-377.

Chojnacki, J. \& Wȩgleńska, T., 1984. Periodicity of composition, abundance, and vertical distribution of summer zooplankton (1977/1978) in Ezcurra Inlet, Admiralty Bay (King George Island, South Shetland). - J. Plank. Res, 6, 997-1017.

Claus, C., 1893. Ueber die Entwicklung und das System der Pontelliden. - Arb. zool. Inst. Univ. Wien $10,233-282$.

Conover, R. J., 1965. Notes on the molting cycle, development of sexual characters and sex ratio in Calanus hyperboreus. - Crustaceana 8, 308-320.

Corkett, C. J. \& McLaren, I, A., 1978. The biology of Pseudocalanus. - Adv. mar. Biol. 15, 1-231.

Ferrari, F. D., 1988. Developmental patterns of ramal segments of copepod post-maxillipedal legs. Crustaceana 54, 256-296.

Fleminger, A., 1973. Pattern, number, variability, and taxonomic significance of integumental organs (sensilla and glandular pores) in the genus Eucalanus (Copepoda, Calanoida). - Fish. Bull. U.S. 71, 965-1010. 
Fleminger, A., 1985. Dimorphism and possible sex change in copepods of the family Calanidae. Mar. Biol. 88, 273-294.

Fleminger, A. \& Hulsemann, K., 1987. Geographical variation in Calanus helgolandicus s.l. (Copepoda, Calanoida) and evidence of recent speciation of the Black Sea population. - Biol. Oceanogr. 5, 43-81.

Frost, B. W., 1989. A taxonomy of the marine calanoid copepod genus Pseudocalanus. - Can. J. Zool. $67,525-551$.

Frost, B. \& Fleminger, A., 1968. A revision of the genus Clausocalanus (Copepoda: Calanoida) with remarks on distributional patterns in diagnostic characters. - Bull. Scripps Instn Oceanogr. tech. Ser. 12, 1-235.

Giesbrecht, W., 1882. Die freilebenden Copepoden der Kieler Foehrde. - Ber. Kommn wiss. Unters. dt. Meere, Kiel 4, 85-168.

Giesbrecht, W., 1892. Systematik und Faunistik der pelagischen Copepoden des Golfes von Neapel. - Fauna Flora Golf. Neapel 19, 1-831.

Giesbrecht, W., 1913. Crustacea. In: Handbuch der Morphologie. Ed. by A. Lang. Fischer, Jena, 4, $1-252$.

Griffiths, A. M. \& Frost, B. W., 1976. Chemical communication in the marine planktonic copepods Calanus pacificus and Pseudocalanus sp. - Crustaceana 30, 1-8.

Heron, G. A. \& Bowman, T. E., 1971. Postnaupliar developmental stages of the copepod crustaceans Clausocalanus laticeps, C. brevipes, and Ctenocalanus citer (Calanoida: Pseudocalanidae). Antarct. Res. Ser. 17, 141-165.

Hirakawa, K. \& Zama, A., 1985. Zooplankton investigations in Lagoon San Rafael and Elefantes Fjord. In: Glaciological studies in Patagonia Northern Icefield 1983-1984. Ed. by Ch. Nakajima. Data Center for Glacier Research, Japanese Society of Snow and Ice, Nagoya, 115-120.

Hulsemann, K., 1985. Two species of Drepanopus Brady (Copepoda Calanoida) with discrete ranges in the Southern Hemisphere. - J. Plankt. Res. 7, 909-925.

Hulsemann, K. \& Fleminger, A., 1975. Some aspects of copepodid development in the genus Pontellina Dana (Copepoda: Calanoida). - Bull. mar. Sci. 25, 174-185.

Hulsemann, K. \& Fleminger, A., 1990. Taxonomic value of minute structures on the genital segment of Pontellina females (Copepoda Calanoida). - Mar. Biol. 105, 99-108.

Jashnov, V. A., 1927. Zooplankton Karskogo morya: - Trudý'plov. morsk. nauch. Inst. 2 (2), 1-59.

Kraefft, F., 1910. Über das Plankton in Ost- und Nordsee und den Verbindungsgebieten, mit besonderer Berücksichtigung der Copepoden. - Wiss. Meeresunters. (Abt. Kiel) 11, 29-99.

Marin, V. \& Antezana, T., 1985. Species composition and relative abundance of copepods in Chilean fjords. - J. Plankt. Res. 7, 961-966.

Mauchline, J., 1988. Taxonomic value of pore patterns in the integument of calanoid copepods (Crustacea). - J. Zool., Lond. 214, 697-749.

Mrázek, A., 1902. Arktische Copepoden. - Fauna arct. 2, 499-528.

Oberg, M., 1906. Die Metamorphose der Plankton-Copepoden der Kieler Bucht. - Wiss. Meeresunters. (Abt. Kiel) 9, 37-103.

Park, T., 1986. Phylogeny of calanoid copepods. - Syllogeus 58, 191-196.

Passano, L. M., 1960. Molting and its control. In: The physiology of Crustacea. Ed. by T. H. Waterman. Acad. Press, New York, 1, 473-536.

Sars, G. O., 1898. The Cladocera, Copepoda and Ostracoda of the Jana Expedition. - Annls Mus. zool. Acad. St. Petersburg 1898, 324-359.

Stephensen, K., 1913. Account of the Crustacea and the Pycnogonida, collected by Dr. V. Nordmann in the summer of 1911 from Northern Strömfjord and Giesecke Lake in West Greenland. - Meddr Grønland 51, 53-77.

Tanaka, O., 1964. Two small collections of copepods from Antarctic. - JARE scient. Rep. (Ser. E: Biol.) 22, 1-20.

Vaupel Klein, J. C. von, 1982a. A taxonomic review of the genus Euchirella Giesbrecht, 1888 (Copepoda, Calanoida). II. The type-species, Euchirella messinensis (Claus, 1863). A. the female of f. typica. - Zool. Verh., Leiden 198, 1-131.

Vaupel Klein, J. C. von, 1982b. Structure of integumental perforations in the Euchirella messinensis female (Crustacea, Copepoda, Calanoida). - Neth. J. Zool. 32, 374-394. 